\title{
Long-range transport of stratospheric aerosols in the Southern Hemisphere following the 2015 Calbuco eruption
}

\author{
Nelson Bègue ${ }^{1}$, Damien Vignelles ${ }^{2}$, Gwenaël Berthet ${ }^{2}$, Thierry Portafaix ${ }^{1}$, Guillaume Payen ${ }^{7}$, Fabrice Jégou ${ }^{2}$, \\ Hassan Benchérif ${ }^{1,6}$, Julien Jumelet ${ }^{3}$, Jean-Paul Vernier ${ }^{4}$, Thibaut Lurton ${ }^{2, a}$, Jean-Baptiste Renard ${ }^{2}$, \\ Lieven Clarisse ${ }^{5}$, Vincent Duverger ${ }^{2}$, Françoise Posny ${ }^{1}$, Jean-Marc Metzger ${ }^{7}$, and Sophie Godin-Beekmann ${ }^{3}$ \\ ${ }^{1}$ Laboratoire de l'Atmosphère et des Cyclones, UMR 8105 CNRS, Université de la Réunion, Reunion Island, France \\ ${ }^{2}$ Laboratoire de Physique et Chimie de l'Environnement et de l'Espace, Université d'Orléans, \\ CNRS UMR7328, Orléans, France \\ ${ }^{3}$ Laboratoire Atmosphère Milieux Observations Spatiales, University of Paris VI, Paris, France \\ ${ }^{4}$ NASA Langley Research Center, Hampton, Virginia, USA \\ ${ }^{5}$ Spectroscopie de l'Atmosphère, Service de Chimie Quantique et Photophysique, Université Libre \\ de Bruxelles, Brussels, Belgium \\ ${ }^{6}$ School of Chemistry and Physics, University of KwaZulu-Natal, Westville, Durban, South Africa \\ ${ }^{7}$ Observatoire des Sciences de l'Univers de La Réunion, UMS3365, Saint-Denis de la Réunion, France \\ ${ }^{a}$ now at: Institut Pierre-Simon-Laplace, UPMC/CNRS, 4 place Jussieu, 75252 Paris Cedex 05, France
}

Correspondence: Nelson Bègue (nelson.begue@univ-reunion.fr)

Received: 12 June 2017 - Discussion started: 22 June 2017

Revised: 2 November 2017 - Accepted: 6 November 2017 - Published: 19 December 2017

\begin{abstract}
After 43 years of inactivity, the Calbuco volcano, which is located in the southern part of Chile, erupted on 22 April 2015. The space-time evolutions (distribution and transport) of its aerosol plume are investigated by combining satellite (CALIOP, IASI, OMPS), in situ aerosol counting (LOAC OPC) and lidar observations, and the MIMOSA advection model. The Calbuco aerosol plume reached the Indian Ocean 1 week after the eruption. Over the Reunion Island site $\left(21^{\circ} \mathrm{S}, 55.5^{\circ} \mathrm{E}\right)$, the aerosol signal was unambiguously enhanced in comparison with "background" conditions, with a volcanic aerosol layer extending from 18 to $21 \mathrm{~km}$ during the May-July period. All the data reveal an increase by a factor of $\sim 2$ in the SAOD (stratospheric aerosol optical depth) with respect to values observed before the eruption. The aerosol mass $e$-folding time is approximately 90 days, which is rather close to the value ( $\sim 80$ days) reported for the Sarychev eruption. Microphysical measurements obtained before, during, and after the eruption reflecting the impact of the Calbuco eruption on the lower stratospheric aerosol content have been analyzed over the Reunion Island site. During the passage of the plume, the volcanic aerosol was characterized by an effective radius of
\end{abstract}

$0.16 \pm 0.02 \mu \mathrm{m}$ with a unimodal size distribution for particles above $0.2 \mu \mathrm{m}$ in diameter. Particle concentrations for sizes larger than $1 \mu \mathrm{m}$ are too low to be properly detected by the LOAC OPC. The aerosol number concentration was $\sim 20$ times higher that observed before and 1 year after the eruption. According to OMPS and lidar observations, a tendency toward conditions before the eruption was observed by April 2016. The volcanic aerosol plume is advected eastward in the Southern Hemisphere and its latitudinal extent is clearly bounded by the subtropical barrier and the polar vortex. The transient behavior of the aerosol layers observed above Reunion Island between May and July 2015 reflects an inhomogeneous spatio-temporal distribution of the plume, which is controlled by the localization of these dynamical barriers.

\section{Introduction}

Stratospheric aerosols affect the chemical and radiation balance of the atmosphere (McCormick et al., 1995; Solomon, 1999; SPARC 2006). The importance of stratospheric 
aerosols on the chemistry is mostly due to its role in the ozone budget (Solomon et al., 1986; Bekki, 1997; Borrmann et al., 1997). Stratospheric aerosols provide sites for heterogeneous chemical reactions leading to stratospheric ozone depletion, which is significantly enhanced in periods of high aerosol loadings following major volcanic eruptions (Solomon, 1999 and references therein). In addition, periods of enhanced stratospheric aerosol loadings can lead to significant warming in the stratosphere and cooling in the troposphere (e.g., McCormick et al., 1995; Solomon et al., 2011; Arfeuille et al., 2013). As reported by Kremser et al. (2016), a better understanding of the processes governing the lifetime of stratospheric aerosols is needed to assess the impacts on climate and chemistry. Since the discovery of the permanent stratospheric aerosol layer, called the Junge Layer, in 1961 (Junge, 1961), it has been established that stratospheric aerosols are mostly composed of sulfuric acid droplets with some more complex characteristics in the stratosphere where organic compounds and meteoritic dust can also contribute to its composition (Froyd et al., 2009; Mossop, 1965; Murphy et al., 1998). The main sources of stratospheric sulfur are carbonyl sulfide (OCS), dimethyl sulfide (DMS), and sulfur dioxide $\left(\mathrm{SO}_{2} ; \mathrm{SPARC}\right.$, 2006), the latter being significantly enhanced after volcanic eruptions (Carn et al., 2015). The injected $\mathrm{SO}_{2}$ into the stratosphere is oxidized into $\mathrm{H}_{2} \mathrm{SO}_{4}$, which (after homogeneous nucleation and/or condensation onto existing aerosol particles) causes an increase in the content of liquid sulfate aerosol (SPARC, 2006). Based on the control of the stratospheric aerosol burden over the last 25 years, Thomason et al. (2007) showed that volcanic effects dominate over natural and anthropogenic sources. Previous studies on stratospheric aerosols have significantly characterized its properties and variability during "background" (i.e., free of volcanic aerosols) and volcanic conditions (e.g., Stenchikov et al., 1998; Jäger and Deshler, 2002; Bauman et al., 2003; Hermann et al; 2003; Hofmann et al; 2009).

The eruption of Pinatubo in 1991 is known to be the last major volcanic eruption, injecting between 14 and $23 \mathrm{Tg}$ of $\mathrm{SO}_{2}$ that significantly perturbed the global stratosphere for several years (Kinninson et al., 1994; McCormick et al., 1995; Stenchikov et al., 1998, 2002; Guo et al., 2004; Dhomse et al., 2014). As reported by Russell et al. (1996), in addition to the prodigious increase in the stratospheric aerosol loading, this event significantly affected numerous aspects of the atmospheric system, including (i) a 2-year cooling of the global surface temperature of several tens of degrees (Canty et al., 2013; Wunderlich and Mitchell, 2017), (ii) a warming of the tropical stratosphere ranging from 1 to $4{ }^{\circ} \mathrm{C}$ (Labitzke and McCormick et al., 1992; Young et al., 1994), and (iii) a lifting of the tropical ozone layer by $\sim 1.8 \mathrm{~km}$ (Pueschel et al., 1992; Grant et al., 1994). Through the use of satellite and balloon-borne observations, various studies have shown that moderate volcanic eruptions (i.e., volcanic explosive index less than or equal to 4) can significantly modulate stratospheric aerosol concentrations (Bourassa et al., 2010; Kravitz et al., 2010; Solomon et al., 2011; Vernier et al., 2011; Clarisse et al., 2012; Jégou et al., 2013). Based upon satellite observations, Vernier et al. (2011) showed that the decadal increase in stratospheric aerosol loadings since 2002 can be attributed to a series of moderate volcanic eruptions. As reported by Kremser et al. (2016), this decadal trend was also obtained from lidar (Hofmann et al., 2009; Trickl et al., 2013; Zuev et al., 2017) and ground-based sun photometer observations (Ridley et al., 2014). Three moderate volcanic eruptions occurred in the 2002-2012 period are ranked in the top 10 of the most influential events on the stratospheric aerosol burden, including (1) the Kasatochi eruption $\left(52.2^{\circ} \mathrm{N}, 175.5^{\circ} \mathrm{W}\right.$; Alaska) in 2008, which injected 1.5-2.5 $\mathrm{Tg}$ of $\mathrm{SO}_{2}$ into the upper troposphere and lower stratosphere (UTLS; Bourassa et al., 2010; Kravitz et al., 2010; Krotkov et al., 2010), (2) the Sarychev eruption in June $2009\left(48.1^{\circ} \mathrm{N}, 153.2^{\circ} \mathrm{E}\right.$; the Kuril Islands), which released $0.9 \mathrm{Tg}$ of $\mathrm{SO}_{2}$ into the UTLS (Clarisse et al., 2012; Kravitz et al., 2011; Jégou et al., 2013), and (3) the Nabro eruption $\left(13.4^{\circ} \mathrm{N}, 41.7^{\circ} \mathrm{E}\right.$; Eritrea) in June 2011, which emitted $1.3 \mathrm{Tg}$ of $\mathrm{SO}_{2}$ into the UTLS (Bourassa et al., 2012; Sawamura et al; 2012). In comparison, these recurrent moderate volcanic eruptions injected 10-20 times less $\mathrm{SO}_{2}$ than the Pinatubo eruption (Solomon et al., 2011). These eruptions can also be used to understand stratospheric dynamics, as was done for the case of the Pinatubo eruption (Trepte et al., 1992).

Indeed, following a volcanic eruption, stratospheric aerosols can be used as a dynamical tracer (Bencherif et al., 2003; Fairlie et al., 2014). Based on satellite observations and a Lagrangian trajectory model, Fairlie et al. (2014) used the dispersion of the Nabro plume to study the dynamics of the Asian monsoon anticyclone. Hitchman et al. (1994) and SPARC (2006) suggested that stratospheric aerosol distributions could be used to understand changes in the Brewer-Dobson circulation. More recently, Ray et al. (2014) combined in situ balloon observations of $\mathrm{SF}_{6}$ and $\mathrm{CO}_{2}$ with a numerical model to show that major explosive volcanic eruptions can induce large-scale changes in the stratospheric circulation via radiative perturbations, improving our understanding of stratospheric transport variability. Aerosol heating in the lower stratosphere induces a westerly wind anomaly and enhanced tropical upwelling (Ray et al., 2014; Pitari et al., 2016a). Using the University of L'Aquila climate-chemistry model (ULAQ-CCM), Pitari et al. (2016a) analyzed the volcanic aerosol perturbation from the eruption of Mt. Pinatubo on the transport of the longlived species $\mathrm{N}_{2} \mathrm{O}$ and $\mathrm{CH}_{4}$. They showed that the observed decline of long-lived greenhouse gases 1 year after the eruption is quantitatively consistent with enhanced stratospheretroposphere exchange due to a change in the Brewer-Dobson circulation. They also revealed that the volcanic aerosol radiative perturbation to stratospheric dynamics may be found by looking at the stratospheric age of air. According to Pitari 
et al. (2016a), enhanced tropical upwelling tends to decrease the tropical age of air and the latitudinal age gradient after major volcanic eruptions. Although most studies discuss major tropical eruptions and their induced dynamical effects, we cannot exclude the possibility that extratropical eruptions in the last 15 years may also have had a significant role in lower stratospheric trends of key dynamical quantities (Kremser et al., 2016).

Previous works have also revealed that stratospheric aerosols can be used to study meridional air mass transport from the tropical stratospheric reservoir (Trepte and Hitchman, 1992; Randel et al., 1993; Chen et al., 1994; Grant et al., 1996, Vernier et al., 2009). Based on satellite observations, Trepte and Hitchman (1992) have shown that transport from the tropics to the midlatitudes is favored during westerly shear phases of the quasi-biennial oscillation (QBO) rather than during the easterly shear phases. More recently, through the use of satellite observations and climate models, Hommel et al. (2015) revealed that the vertical and latitudinal extent of the stratospheric aerosol layer (between 16 and $31 \mathrm{~km}$ ) in the tropics is modulated by the QBO. Pitari et al. (2016b) analyzed the radiative perturbations in the stratosphere induced by the last five major volcanic eruptions after 1960 (i.e, Agung, Mount St. Helens, El Chichón, Nevado del Ruiz, and Pinatubo) using a climate model that included an aerosol microphysics module for aerosol formation and growth. They found an increase in stratospheric temperature associated with a significant impact on tropical upwelling. The impact on stratospheric upwelling is found to be larger when the volcanically perturbed stratospheric aerosols are confined to the tropics, as tends to be the case for eruptions that are followed for several months by easterly shear of the QBO. They showed that the Nevado del Ruiz and Pinatubo eruptions occurred during years with dominant QBO easterly shear, which led to the confinement of the aerosols near the Equator with less poleward transport. This tropical confinement produced a larger latitudinal gradient of the perturbation heating rate and a stronger impact on the tropical upwelling (Pitari et al., 2016b). It is worth noting that the life cycle of an aerosol is affected by sedimentation. The fact that sulfuric particles grow larger following major eruptions (e.g., Russell et al., 1996; Bauman et al., 2003) means they can sediment appreciably during transport within the stratosphere, causing the plume transport to diverge from the expected isentropic trajectory. Even in moderate eruptions for which sulfuric particle growth may not be significant, the accommodation of sulfur onto ultrafine ash particles has the potential to also change the fate of a proportion of the volcanic plume.

This paper reports on the Calbuco plume observations over Reunion Island $\left(20.5^{\circ} \mathrm{S}, 55.5^{\circ} \mathrm{E}\right)$ and its transport in the southern tropics. The geometrical and optical properties of the Calbuco plume are inferred from the ground-based observations at Reunion Island in the framework of the MORGANE (Maïdo ObservatoRy Gas Aerosols NDACC Exper- iment) campaign. The aim of this study is to provide a description of the dynamical context that has favored the spread of the Calbuco plume in the Southern Hemisphere. The paper is organized as follows: Sect. 2 describes the observations and the model used for the investigation of the volcanic aerosol transport. A description of the long-range transport of the volcanic plume over the Indian Ocean is provided in Sect. 3; Sect. 4 gives a dynamical analysis of this case study, and the summary and the conclusions are given in Sect. 5.

\section{Instrumentation and model description}

\subsection{Observations}

\subsubsection{Ground-based lidar}

One part of the observations used in this study was performed during the MORGANE campaign, which took place at the Maïdo observatory on Reunion Island in May 2015. The MORGANE ground-based observational systems combine lidar and balloon-borne payloads to study the composition and the dynamics of the UTLS in the Southern Hemisphere. Among measurement data from four lidar systems operated during this campaign, we used data from the Differential Absorption Lidar (DIAL) system built for stratospheric ozone monitoring (Baray et al., 2013). It is also possible to retrieve aerosol profiles in the $15-38 \mathrm{~km}$ altitude range from these measurements. This instrument has been in operation at the Maïdo observatory since early 2013. The technical details and evaluation of its performance are given by Baray et al. (2013). A brief description of this DIAL system follows. It uses a frequency-tripled Nd: YAG laser, which provides a beam at $355 \mathrm{~nm}$ of wavelength, with a repetition rate of $30 \mathrm{~Hz}$ and a $\mathrm{XeCl}$ excimer laser that emits radiation at $308 \mathrm{~nm}$ at $40 \mathrm{~Hz}$. The optical receiver is a telescope composed of four parabolic mirrors with which the backscattered signal is collected by four optical fibers located at the focal points. The current configuration of the DIAL system mainly detects signals in the UV regions of the spectrum $(308,332,355$, and $387 \mathrm{~nm}$ ). The lidar dataset used in this study consists of daily records of backscattering signals obtained from the Maïdo facility between 1 November 2014 and 30 November 2016 (106 profiles). It should be noted that no measurements were recorded at Reunion Island from January to April 2016 because of technical problems. The daily measurements are nighttime and time integrated over about $3 \mathrm{~h}$ on average.

We used the methodology described by Sasano (1985) to obtain the extinction and backscatter coefficient from a Rayleigh-Mie lidar. This methodology is similar to the approach of Klett (1981) with the advantage of providing a numerical calculation of the extinction and backscatter coefficient. Temperature and pressure profiles are needed to retrieve optical properties from this approach. For this study, temperature and pressure profiles obtained from a radioson- 
des launched from Roland Garros Airport at 11:00 (UTC) are used. In order to obtain a complete temperature and pressure profile range from the ground to the mesosphere, we used the Arletty atmospheric model (Hauchecorne et al., 1998; Nair et al., 2012) based on data from the European Centre for Medium-Range Weather Forecasts (ECMWF). The altitude of reference is determined for each profile. On average, the reference altitude is located between 30 and $40 \mathrm{~km}$. Another parameter that we need to retrieve the optical properties is the ratio of backscatter and the extinction coefficient for aerosol, also called lidar ratio. For background stratospheric aerosol, the value found in the literature is near 60 (Trickl et al., 2013; Ridley et al., 2014; Sakai et al., 2016; Khaykin et al., 2017). This value is commonly used for volcanically quiescent conditions and periods of moderate eruptions (Sakai et al., 2016). The lidar ratio depends on the particle size distribution and the type of aerosol (Jäger and Deshler, 2002; Young and Vaughan, 2009). Error in the lidar ratio could significantly influence the uncertainty in aerosol extinction and optical depth (Sakai et al., 2016; Khaykin et al., 2017). Moreover, it should be noted that new approaches to derive extinction from lidar, which also measure depolarization, have been developed and already applied to spaceborne lidar such as CALIOP (Young and Vaughan, 2009).

\subsubsection{Balloon-borne OPC}

In order to analyze the evolution of the concentration and the size of the observed aerosols over the Reunion Island site, many LOAC (light optical aerosol counter) systems were launched together with balloon ozonesondes. A detailed description of the LOAC is given by Renard et al. (2016). In brief, LOAC is a lightweight optical particle counter (OPC) of $1 \mathrm{~kg}$ that can fly under latex weather balloons. Through measurements of the light scattered by particles at two specific angles (Lurton et al., 2014), the LOAC provides aerosol concentrations and particle size distributions for 19 size classes ranging from 0.2 to $50 \mu \mathrm{m}$ in diameter every $10 \mathrm{~s}$ with a vertical resolution of nearly $50 \mathrm{~m}$ depending on the ascent rate of the balloon. The number concentration range is from 0.6 to a few thousand particles per $\mathrm{cm}^{3}$ (Vignelles, 2017). Uncertainties in number concentration during the ascent under the meteorological balloon are mainly due to temperature variation effects on electronics (Renard et al., 2016; Vignelles, 2017). Uncertainties in number concentrations for size bins smaller than $1 \mu \mathrm{m}$ is estimated to be $\pm 30 \%$. For larger size bins, uncertainties in number concentration are governed by Poisson statistics and estimated to be \pm 20 and $\pm 60 \%$ at particle concentrations lower than $10^{-1}$ and $10^{-2} \mathrm{~cm}^{-3}$, respectively.

\subsubsection{CALIOP}

The Cloud-Aerosol Lidar with Orthogonal Polarization (CALIOP) onboard the Cloud-Aerosol Lidar and Infrared
Pathfinder Satellite Observation (CALIPSO) was used to study the transport of the Calbuco plume. CALIPSO was launched into a sun-synchronous polar orbit in 2006 (Winkler et al., 2009) with a repeat cycle of 16 days. CALIPSO is composed of an infrared imager radiometer (IIR), a wide field visible camera, and the CALIOP lidar. CALIOP is a two-wavelength polarization-sensitive lidar (532 and $1064 \mathrm{~nm}$ ) that measures total attenuated backscatter vertical profiles with altitude-varying vertical $(30-300 \mathrm{~m})$ and horizontal (300-5000 m) resolution (Winker et al., 2009). The data used in this study are the total and perpendicular backscatter coefficient at $532 \mathrm{~nm}$, available from the CALIOP level 1B v4.01 product. These data have been averaged every $1^{\circ}$ in latitude for each orbit and grouped into data files containing 16 days of measurements. From there, the scattering ratio and depolarization ratio at $532 \mathrm{~nm}$ have been calculated (Vernier et al., 2009). Through the use of this algorithm, the full zonal means of the scattering ratio between $20^{\circ} \mathrm{S}$ and $20^{\circ} \mathrm{N}$ are obtained by averaging 7200 cells, leading to a precision of $\pm 1.6 \%$ (Vernier et al., 2009). The ability of CALIOP to detect small volcanic plumes in the lower tropical stratosphere has been highlighted in previous studies (Thomason et al., 2007; Vernier et al., 2009, 2011).

\subsubsection{IASI}

The Infrared Atmospheric Sounding Interferometer (IASI) observations were used to quantify the amount of $\mathrm{SO}_{2}$ emitted during the Calbuco eruption. IASI is a nadir view thermal infrared sounder onboard the Meteorological Operational satellite (MetOp-A and MetOp-B). The IASI observations used in this study were realized from the MetOp-A platform, which launched in October 2006. The IASI global spatial coverage and footprint of $12 \mathrm{~km}$ make it relevant for monitoring the key atmospheric species, particularly volcanic $\mathrm{SO}_{2}$ (Clarisse et al., 2008, 2012; Clerbaux et al., 2009). The amount and altitude of emitted $\mathrm{SO}_{2}$ were obtained from the algorithms detailed in Clarisse et al. (2012) and Clarisse et al. (2014), respectively. For each IASI observation, the altitude was estimated first, after which the column was calculated using the altitude information as an input parameter.

\subsubsection{OMPS}

The Ozone Mapper and Profiler Suite (OMPS) limb profiler (LP) is also used in the present study to analyze the optical properties of the volcanic plume over the Reunion Island site. OMPS was launched in October 2011 onboard the Suomi National Polar Partnership (NPP) spacecraft. The data used in this study are the daily extinction profiles at $675 \mathrm{~nm}$. A detailed description of the aerosol extinction retrieval algorithm is given by Jaross et al. (2012) and Rault and Loughman (2013). The aerosol extinction profiles are retrieved from the scattering solar radiation. The aerosol extinction rates are retrieved using spectral channels with weak 
gaseous absorption. The Rodgers maximum likelihood technique is used to retrieve the aerosol extinction profiles independently for each wavelength $s$ (Taha et al., 2011). We used 2 years (from November 2014 to November 2016) of satellite overpasses above the lidar site, within a $5^{\circ} \times 5^{\circ}$ latitude and longitude grid. OMPS data have already been used to effectively detect and characterize major events, such as the Chelyabinsk bolide in February 2013 (Gorkavyi et al., 2013).

\subsection{MIMOSA model}

The Modèle Isentropique de transport Mésoéchelle de l'Ozone Stratosphérique par Advection (MIMOSA) model (Hauchecorne et al., 2002) is a potential vorticity (PV) advection model running on isentropic surfaces (surface of constant potential temperature). The advection scheme is semi-Lagrangian with a time step of $1 \mathrm{~h}$. The re-gridding onto the original orthonormal grid is performed every $6 \mathrm{~h}$. The model resolution is $0.5^{\circ} \times 0.5^{\circ}$. The advection is driven by ECMWF meteorological analyses at a resolution of $0.5^{\circ} \times 0.5^{\circ}$. In the case of the PV, its slow diabatic evolution is taken into account by relaxing the model PV towards the PV calculated from the ECMWF fields with a relaxation time of 10 days. Using this procedure, it is possible to run the model continuously and follow the evolution of PV filaments for several months. The accuracy of the model has been evaluated by Hauchecorne et al. (2002) and validated against airborne lidar ozone measurements using a correlation between PV and ozone, a quasi-conserved chemical tracer on timescales of a week or so within most of the lower stratosphere (Heese et al., 2001; Jumelet et al., 2009). The MIMOSA model can also be used to determine the origin of air masses influencing a given site, similar to an isentropic Lagrangian trajectory model. The MIMOSA model is frequently used to detect the origin of air masses inducing laminae on ozone profiles (Hauchecorne et al., 2002; Godin et al., 2002; Portafaix et al., 2003).

\subsection{DyBAL code}

The Dynamical BArrier Location (DyBAL) code is original software developed at the Laboratoire de l'Atmosphere et des Cyclones (LACy, France) to detect barriers to mixing in the subtropical stratosphere (Portafaix et al., 2003). The dynamical barriers are detected from the equivalent length of the tracer contour and the gradient of isentropic Ertel potential vorticity (PV) in equivalent latitude coordinates as defined by Nakamura (1996). These two diagnostic tools are used by DyBAL to identify weak mixing and transport barriers. The position of the dynamical barrier is characterized by a local maximum of the PV gradient and a local minimum of the equivalent length (Nakamura, 1996). The DyBAL code is applied to the PV map obtained from the MIMOSA model runs. The ability of DyBAL to detect the position and the deformation of the dynamical barriers has been highlighted in

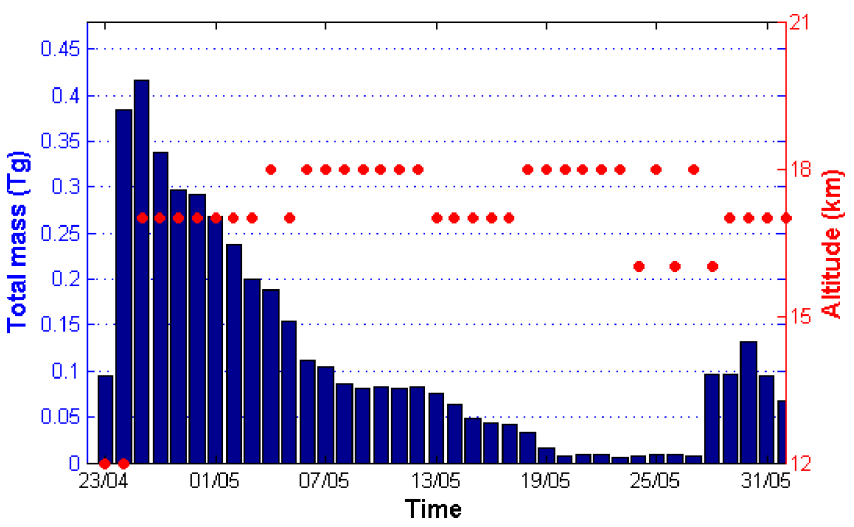

Figure 1. Evolution of the $\mathrm{SO}_{2}$ total column mass (in blue) and the altitude of the maximum $\mathrm{SO}_{2}$ mass (red dots) obtained from IASI from 23 April 2015 to 31 May 2015 over the Southern Hemisphere. The altitude of the maximum $\mathrm{SO}_{2}$ mass was obtained from the algorithms detailed in Clarisse et al. (2014).

previous studies (Bencherif et al., 2007; Morel et al., 2005; Portafaix et al., 2003).

\section{Long-range transport and evolution of the Calbuco volcanic plume over the Indian Ocean}

\subsection{Plume formation and transport}

\subsection{1 $\mathrm{SO}_{2}$ plume}

After 43 years of inactivity, Calbuco erupted on 22 April 2015 and two intense explosive events were recorded during the same week. The evolution of the $\mathrm{SO}_{2}$ total mass measured by IASI between 23 April 2015 and 31 May 2015 is reported in Fig. 1. The $\mathrm{SO}_{2}$ total mass is defined as the sum of the $\mathrm{SO}_{2}$ mass over the atmospheric column from midday to midnight over the Southern Hemisphere. As expected an increase in the $\mathrm{SO}_{2}$ amounts was observed by IASI a few days following the Calbuco eruption. One day after the eruption the $\mathrm{SO}_{2}$ total mass was 10 times higher than background levels. The $\mathrm{SO}_{2}$ total mass increased quickly to its maximum value $(0.41 \mathrm{Tg})$ on 25 April 2015 and slowly decreased to reach values close to the background values on 19 May 2015 (Fig. 1). The $\mathrm{SO}_{2} e$-folding time was estimated to be about 11 days, which is in agreement with the time value reported for the 2009 Sarychev volcanic eruption (Jégou et al., 2013). The $\mathrm{SO}_{2}$ total mass increased again on 28 May 2015 to reach a secondary maximum $(0.13 \mathrm{Tg})$ on 30 May 2015 . This new increase in the $\mathrm{SO}_{2}$ total mass could be due to the Wolf eruption (Isabela Island, Galapagos), which occurred on 25 May 2015 (Xu et al., 2016). The maximum $\mathrm{SO}_{2}$ total mass $(0.41 \mathrm{Tg})$ emitted during the Calbuco eruption was about two 2 times lower than the maximum value $(0.9 \mathrm{Tg})$ emitted from the Sarychev eruption $(0.9 \mathrm{Tg})$ in June 2009 


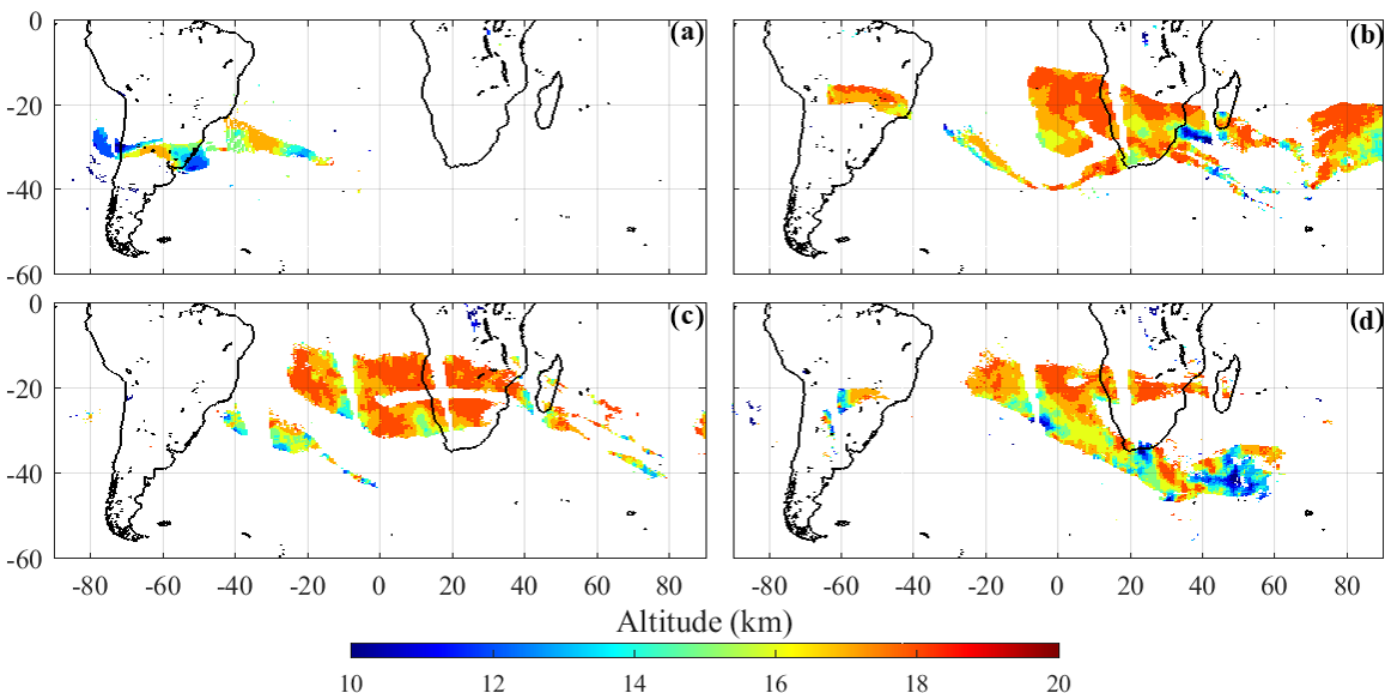

Figure 2. Injection altitude $(\mathrm{km})$ and transport of $\mathrm{SO}_{2}$ obtained from IASI observations on (a) 24 April, (b) 1 May, (c) 6 May, and (d) 11 May.

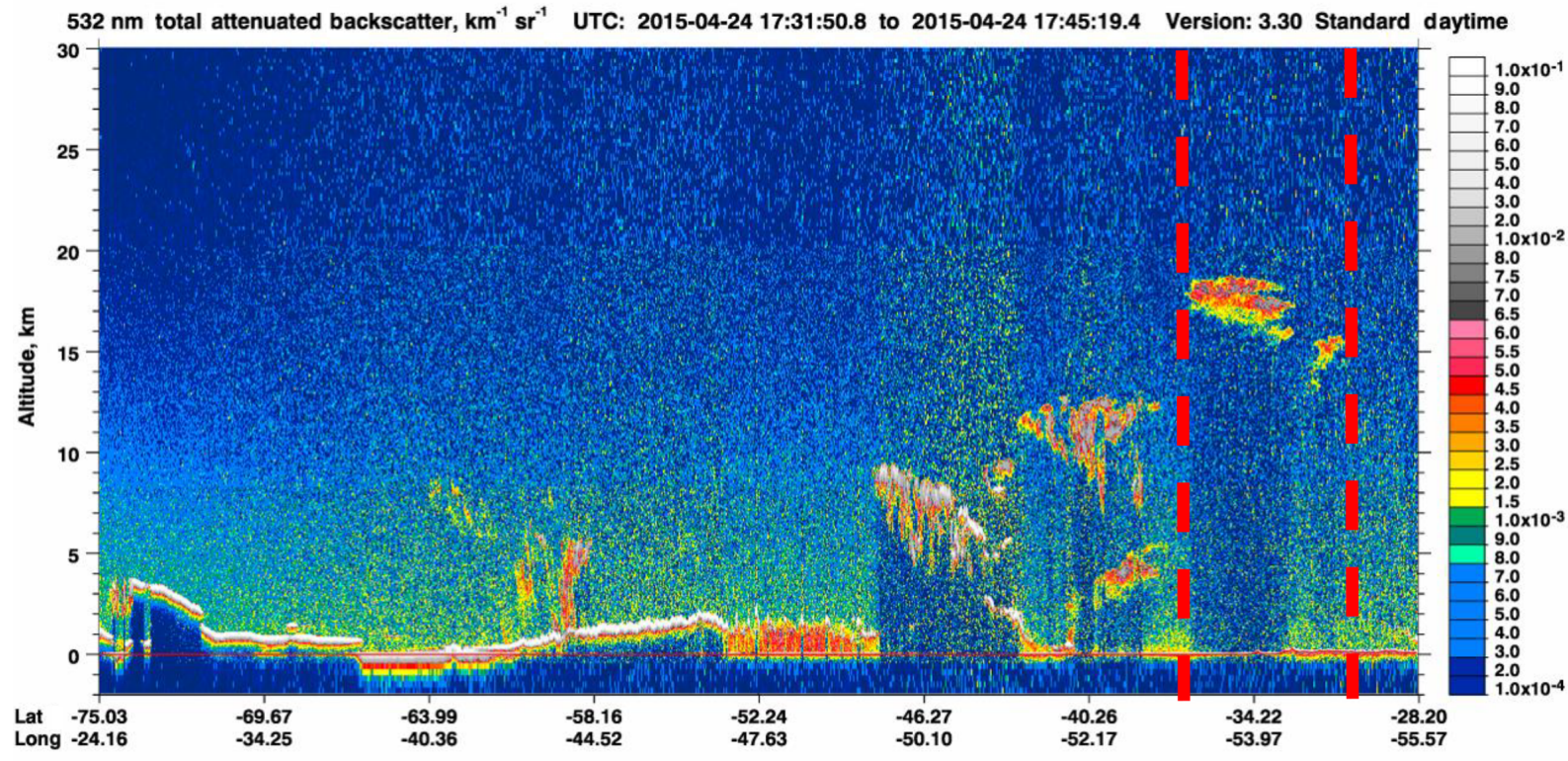

Brightness_temperature_difference_8.65-12.05, $\mathrm{K}$

Figure 3. CALIOP cross section of $532 \mathrm{~nm}$ attenuated backscatter and brightness temperature difference for the overpass at 17:30-17:45 UTC on 24 April 2015 over South America from 28 to $75^{\circ} \mathrm{S}$ latitude. The two red dashed lines delimit the geographical region where the Calbuco plume is observed by CALIOP on 24 April 2015.

(Jégou et al., 2013). It is also worth noting that the $\mathrm{SO}_{2}$ mass injected during the Calbuco eruption is of the same order as for the Grímsvötn eruption in May 2011 (Clarisse et al., 2011). Figure 2 also depicts the maximum altitude of $\mathrm{SO}_{2}$ over the period from 23 April 2015 to 31 May 2015. On average the maximum altitude of $\mathrm{SO}_{2}$ is located in the lower stratosphere region around $17 \mathrm{~km}$. 


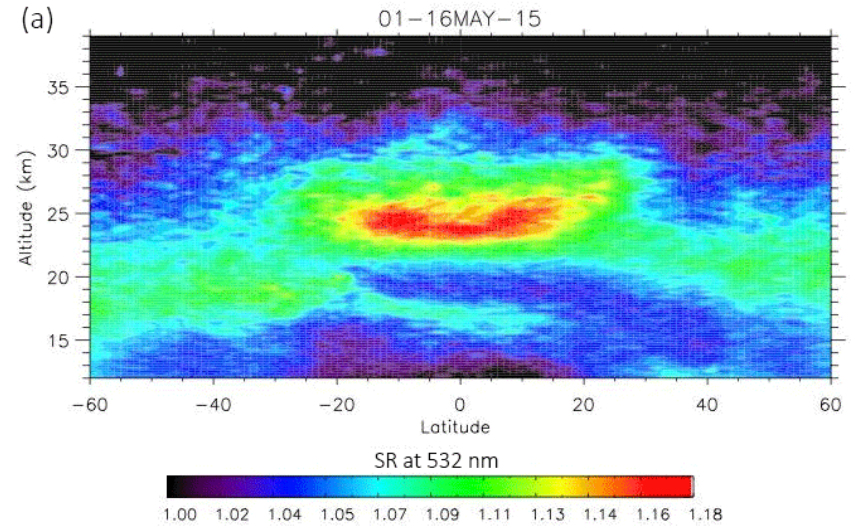

(b)

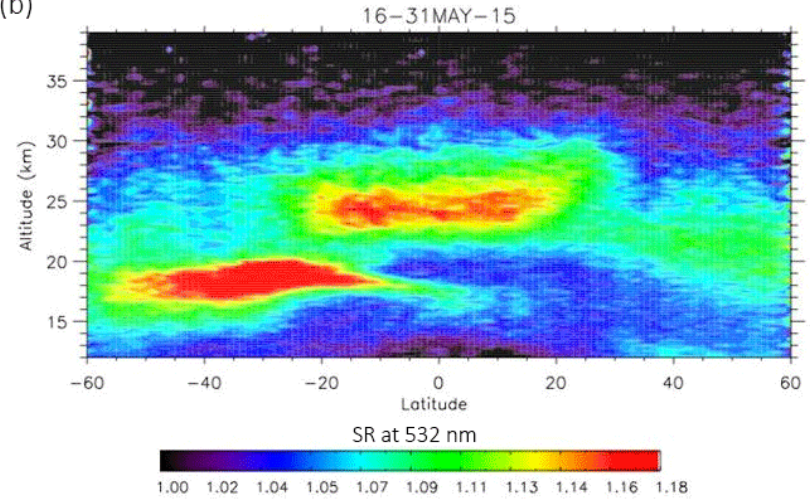

Figure 4. Half monthly mean of the zonal scattering ratio at $532 \mathrm{~nm}$ on (a) 1-15 May (1-2 weeks after eruption) and (b) 16-31 May (3-4 weeks after eruption).

The $\mathrm{SO}_{2}$ measurements integrated from midday to midnight obtained from IASI are also used to describe the transport of the volcanic plume over the Southern Hemisphere (Fig. 2). On 23 April 2015, a part of the Calbuco plume passed close to the Uruguay coast at an altitude of $17 \mathrm{~km}$ and was then transported by the general circulation. The plume reached southern Africa and the east side of Madagascar on 1 May 2015 at altitude of $17-18 \mathrm{~km}$ and was organized following a cyclonic rolling (Fig. 2b). On 6 May, the plume was mainly located over the Atlantic Ocean near the west coast of South Africa and partly over Namibia and South Africa. As expected, the $\mathrm{SO}_{2}$ plume extent and amplitude began to diminish on 11 May 2015 through the oxidation of $\mathrm{SO}_{2}$ to gaseous sulfuric acid, which is further converted into $\mathrm{H}_{2} \mathrm{SO}_{4}-\mathrm{H}_{2} \mathrm{O}$ liquid aerosol. The plume was embedded in a thin $15-17 \mathrm{~km}$ altitude atmospheric layer, extending from the Atlantic Ocean to the Indian Ocean and passing over the Cape of Good Hope (Fig. 2d).

\subsubsection{Spatial extent of the aerosol plume}

The transport of the volcanic aerosol plume over the Southern Hemisphere can be followed by CALIOP observations at $532 \mathrm{~nm}$. Figure 3 shows the CALIOP cross section of the $532 \mathrm{~nm}$ total attenuated backscatter (TAB) for the overpass over South America on 24 April. The TAB signals ranging from $1 \times 10^{-3}$ to $5 \times 10^{-3} \mathrm{~km}^{-1} \mathrm{sr}^{-1}$ corresponding to weak values of brightness temperatures over the southern part of Brazil $\left(34.22^{\circ} \mathrm{S}, 53.97^{\circ} \mathrm{W}\right)$ can be attributed to volcanic material injected up to the lower stratosphere by the Calbuco eruption. Figures 4 and 5 present the latitude-altitude cross sections of the scattering ratio observed by CALIOP for 16day selected periods in 2015. The data displayed in Figs. 4 and 5 correspond to the zonal mean averages of the CALIOP scattering ratio during 16-day periods. The data are calculated within $1^{\circ}$ latitudinal zonal bands and have about $9 \%$ error (Vernier et al., 2009). The scattering ratio (SR) values observed during the 16-30 April period (before the eruption) in the Southern Hemisphere, particularly in the lower stratosphere, were on average 1.05 (not shown). Between 1 and 3 weeks after the eruption (1-16 May period), CALIOP observations reveal that SR increased up to 1.12 in the southern lower stratosphere (Fig. 4a). The amplitude of the plume during the first weeks following the eruption was higher than the background aerosol levels at the midlatitudes but was still below the scattering ratio values observed in the tropics. The first weeks following the eruption correspond to the period when the $\mathrm{SO}_{2}$ is still being converted into $\mathrm{H}_{2} \mathrm{SO}_{4}-$ $\mathrm{H}_{2} \mathrm{O}$ liquid aerosols (Fig. 1). The elevated backscatter in the tropics could be attributed to possible remnants of the $\mathrm{Ke}$ lud $\left(7.5^{\circ} \mathrm{S}, 112.2^{\circ} \mathrm{E}\right.$; erupted in February 2014) volcanic aerosol superimposed to the equatorial background aerosol layer (Kristiansen et al., 2015). About 1 month after the eruption (16-31 May period) the Calbuco plume was much more pronounced with scattering ratio values (ranging from 1.16 to 1.18) largely above the values observed before the eruption from CALIOP and greater than aerosol amounts confined in the tropical reservoir (Fig. 4b). The second half of May (16-31 May) corresponds to the period when $\mathrm{SO}_{2}$ has been oxidized to aerosol. The plume extended up to about $20 \mathrm{~km}$ in altitude and spread over a wide range of latitudes, nearly reaching $60^{\circ} \mathrm{S}$ and intruding into the low latitudes near $5^{\circ} \mathrm{S}$. About 1 month later (16-30 June), the plume top had moved upward by several hundred meters and the layer was thicker (Fig. 5a). The Southern Hemisphere between $10^{\circ} \mathrm{S}$ and the polar latitudes was full of volcanic aerosols with scattering ratio values much higher than elsewhere in the whole stratosphere. About 4 months after the eruption (16-31 August) the volcanic aerosol layer was even thicker with scattering ratios remaining high (Fig. 5b). Figure 5b also reveals a deepening of the volcanic aerosol layer and an enhancement of the equatorial backscatter in the upper troposphere.

In the $21-28 \mathrm{~km}$ altitude range, the detrainment of aerosols from the equatorial reservoir depends upon the phase of the QBO and on the intensity of planetary wave activity (Trepte and Hitchman, 1992). Through the use of a numerical model, Pitari et al. (2016b) discussed the impact of the QBO phase on the meridional transport of the aerosol plume to middle 

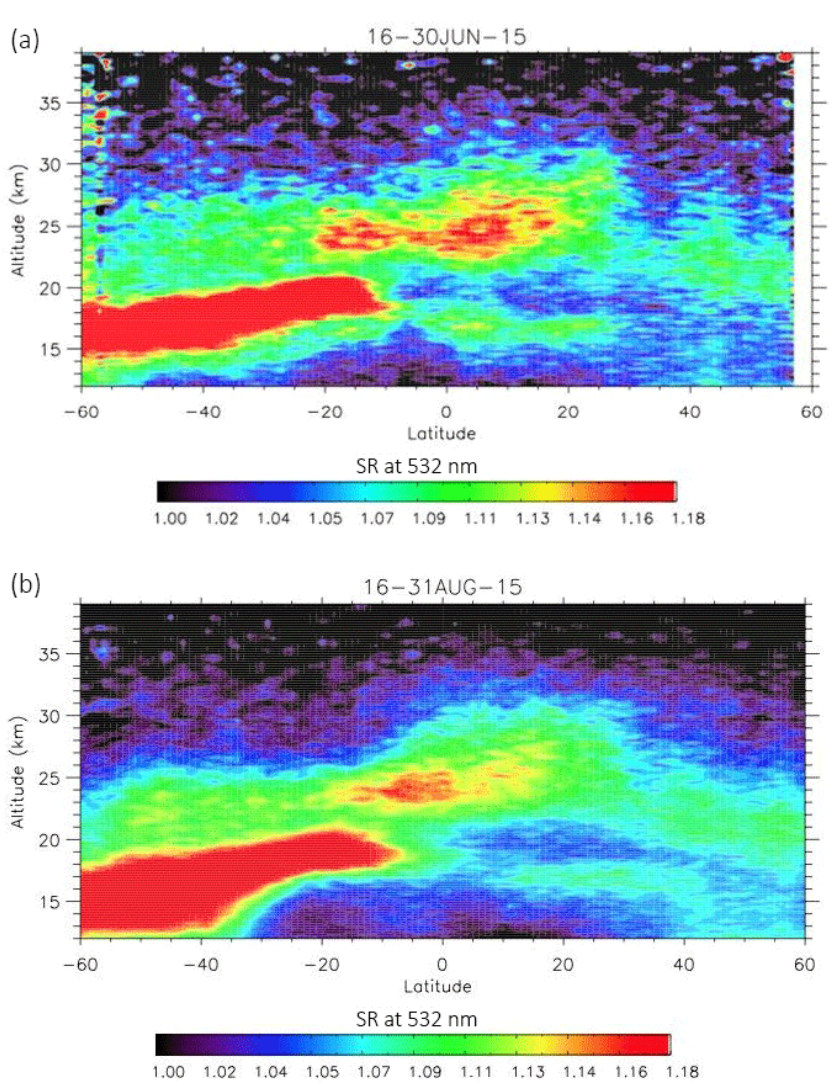

Figure 5. Half monthly mean of the zonal scattering ratio at $532 \mathrm{~nm}$ on (a) 16-30 June (2 months after eruption) and (b) 16-31 August (4 months after eruption).

and high latitudes. They revealed that the volcanic aerosols are confined to the tropics when a volcanic eruption occurs during the easterly shear of the QBO. When QBO easterlies descend in the tropics, the propagation of planetary waves is inhibited from entering this region, thus limiting the extent to which these waves may detrain aerosol laterally from the tropical reservoir (Trepte et al., 1993). This corresponds to the situation in April-May 2015 (Fig. 4a, b). However, during the westerly phase of the QBO, mixing across the subtropics is favored, especially in winter (Trepte et al., 1993). The meridional spread in aerosols to southern midlatitudes shown above $21 \mathrm{~km}$ in Fig. 5a and b is consistent with the phase reversal of the QBO from easterlies to westerlies observed from mid-2015.

\subsection{Evolution of the aerosol plume over the Reunion site}

\subsubsection{Ground-based and satellite observations}

Figure 6 depicts the evolution of the stratospheric AOD (SAOD) at $532 \mathrm{~nm}$ calculated between 17 and $30 \mathrm{~km}$ from the Reunion ground-based lidar and OMPS observations over Reunion Island from November 2014 to November 2016.

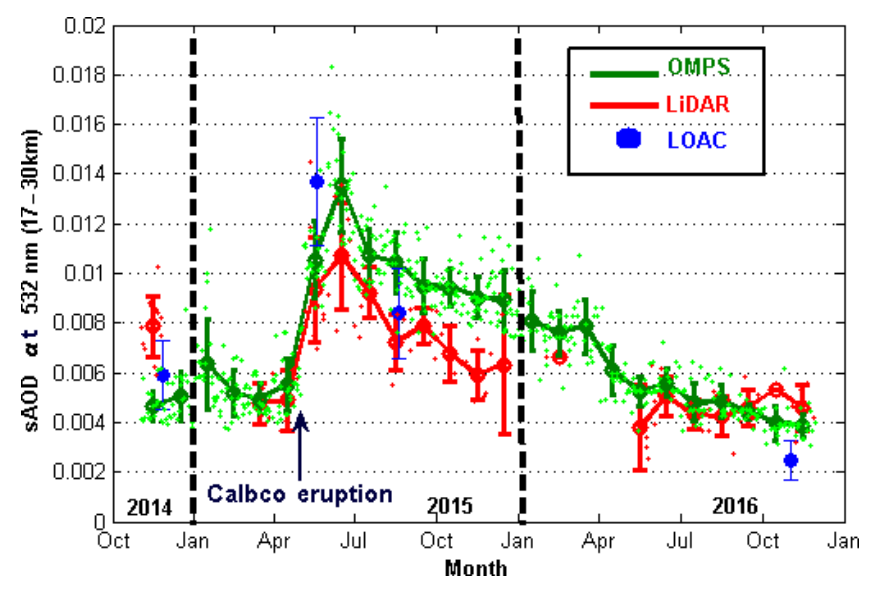

Figure 6. Evolution of SAOD calculated between 17 and $30 \mathrm{~km}$ at $532 \mathrm{~nm}$ from lidar (red), LOAC OPC (blue), and OMPS (green) observations between November 2014 and November 2016 over the Reunion site. The small dots represent the daily SAOD and the large dots represent the monthly averaged SAOD obtained from OMPS and lidar observations. The large blue dots represent the SAOD calculated from LOAC OPC observations over Reunion on 26 November 2014, 19 May 2015, 19 August 2015, and 2 November 2016. The error bars associated with lidar and OMPS observations represent the standard deviation. The error bars associated with LOAC OPC represent the uncertainty values. The date of the Calbuco eruption is indicated by a blue arrow.

The wavelength conversions to $532 \mathrm{~nm}$ were performed using the Ångström exponents; a detailed description of the methodology is given by Khaykin et al. (2017). The Ångström exponents for the $355-532 \mathrm{~nm}$ and $532-675 \mathrm{~nm}$ pairs were adopted from Jäger and Deshler (2002) and Khaykin et al. (2017) and set to -1.3 and -1.8 , respectively. SAOD values were calculated from lidar and OMPS observations at $532 \mathrm{~nm}$ using the Ångström exponent mentioned previously. As expected, an increase in the aerosol loading was observed over the Reunion site a few weeks after the Calbuco eruption. OMPS data show a doubling in the SAOD record in comparison with values observed at the end of 2014 and at the beginning of 2015 (Fig. 6). SAOD reached its maximum values (0.014 for OMPS) at the beginning of June 2015, decreased afterward to 0.01 on August 2015, and went back to pre-eruption values (0.004-0.006) in April 2016. The lidar records peaks at the same period, but SAOD values are 1.2 times weaker than those observed by OMPS during the June-December period. The lidar SAOD observations show less difference with values obtained prior to the eruption (0.008). Discrepancies between OMPS and lidar were significantly reduced by April 2016 (cf. relative differences of $25 \%$ over the January-December 2015 period and $10 \%$ over the April-November 2016 period). From both datasets an aerosol $e$-folding of approximately 90 days can be derived, which is rather close to the value ( $\sim 80$ days) reported for the Sarychev eruption (Jégou et al., 2013). 
(a)

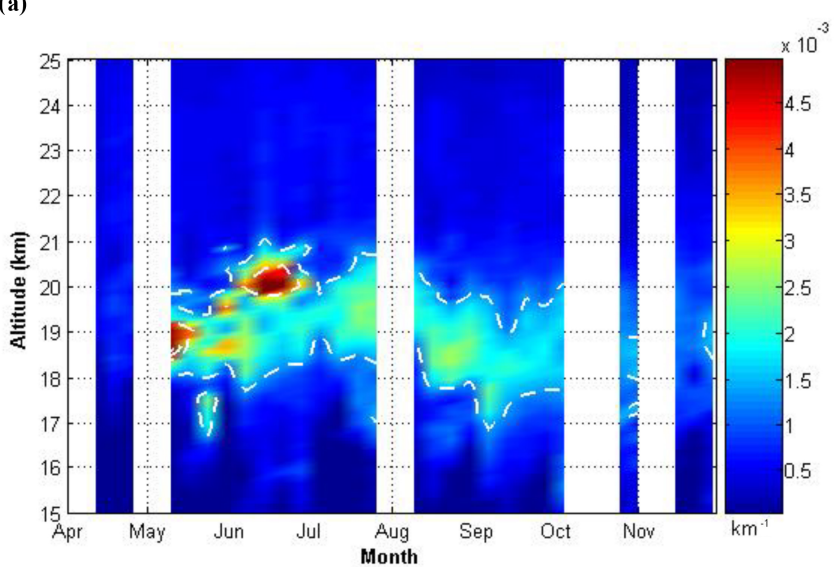

(b)

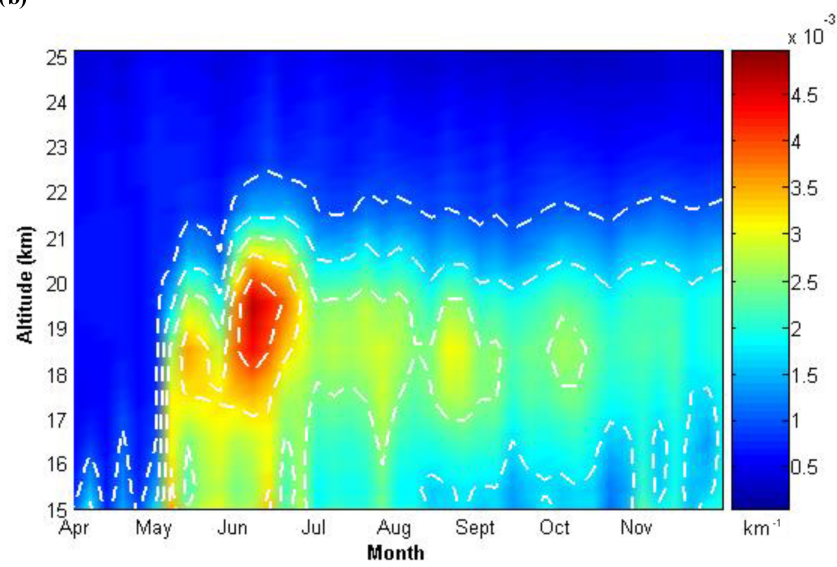

Figure 7. Time series of weekly averaged profiles of extinction at $532 \mathrm{~nm}$ obtained from (a) ground-based lidar and (b) OMPS observations over Reunion between April 2015 and December 2015.

Figure 7a illustrates the weekly averaged extinction profiles at $532 \mathrm{~nm}$ derived from lidar measurements over Reunion Island. This figure reveals a sharp increase in the extinction between 18 and $19 \mathrm{~km}$ in May 2015 reaching its maximum value (greater than $4 \times 10^{-3} \mathrm{~km}^{-1}$ ) in June. The vertical extent of the plume had increased significantly over the May-July period with a volcanic aerosol layer spanning from 18 to $21 \mathrm{~km}$. At the beginning of June, the plume was structured in two layers with the first centered at $18.5 \mathrm{~km}$ and the second at $20 \mathrm{~km}$ (Fig. 7a). We also note a brief decrease in the local extinction ranging from 1.5 to $3 \mathrm{~km}^{-1}$ around mid-May. The variability observed in the weekly averaged extinction profiles and in the vertical extent of the aerosol signal over the May-July period reflects the presence of transient aerosol layers above Reunion Island and indicates that the plume is not homogeneously distributed at this stage. The altitude of the volcanic aerosol plume and the extinction values decreased from mid-August onwards. The plume is hence centered around $18 \mathrm{~km}$ in September, and extinction values in September are around 2 times less than those observed in June. This decrease in the extinction values is accompanied by a decrease in the altitude of the plume and could be due to the sedimentation processes (Fig. 7a). Hamill et al. (1997) revealed that sedimentation can play a significant role in the loss of stratospheric aerosols to the troposphere. Overall, the temporal evolution of the weekly averaged extinction presents similar general features as the lidar observations, with maximum values in June and a subsequent gradual decrease in the aerosol signal. Nevertheless, in the OMPS data the plume is smeared out over a wider vertical range than in the lidar record (Fig. 7b). The vertical and horizontal structures of the plume are not reproduced in the OMPS data. In particular, the decrease in the plume altitude in mid-August is not observed by OMPS. More generally, extinction values observed by OMPS in the $15-17 \mathrm{~km}$ altitude range are higher than those observed by the lidar. The evolution of the scattering ratio at $532 \mathrm{~nm}$ obtained from the lidar and CALIOP spaceborne observations during the April-December 2015 period over the Reunion Island site are presented in Fig. 8. The scattering ratios from CALIOP have been averaged within $\pm 5^{\circ}$ latitude and $\pm 50^{\circ}$ longitude (extending from Africa to Australia) around Reunion Island (Fig. 8b). CALIOP observations confirm the presence of the volcanic aerosol plume over the Reunion Island site at the beginning of May 2015 with maximum scattering ratio values (greater than 1.9) in mid-May 2015. Overall, the aerosol variability is smoother in CALIOP observations than in the lidar record, which shows more fluctuations in the altitude of the volcanic plume. In contrast to the lidar and OMPS observations, CALIOP data do not show an increase in the vertical extent of the plume or maximum scattering ratio values at the beginning of June 2015. According to CALIOP, the scattering ratio begins to decrease in mid-June followed by a slight decrease in the altitude of the plume from the end of July (Fig. 8b). From July onwards, the CALIOP aerosol scattering ratios decrease gradually with similar values as observed by the lidar. The decrease in the aerosol scattering ratio is associated with a descent in the altitude of the plume, which could be due to sedimentation and is consistent with the observations from OMPS.

The reasons for these discrepancies between ground-based and satellite observations may be multiple, but effects due to different spatial samplings cannot be excluded. The difference in vertical resolution between ground-based lidar and satellites (OMPS, CALIOP) could be one possible cause of the discrepancies. The discrepancies between the satellites and ground-based lidar could be significant when the difference in vertical resolution is high between these devices. We note that the vertical resolution of OMPS is 10 times lower than the ground-based lidar at 1.5 and $0.15 \mathrm{~km}$, respectively (Jaross et al., 2012). Thus, the structures of the plume look smoother than those obtained from the groundbased lidar. In the case of CALIOP for which the vertical resolution is better ( $\sim 3$ times less to the ground-based lidar), the differences in the structure of the plume are less. Moreover, the discrepancies between the results presented in 
(a)

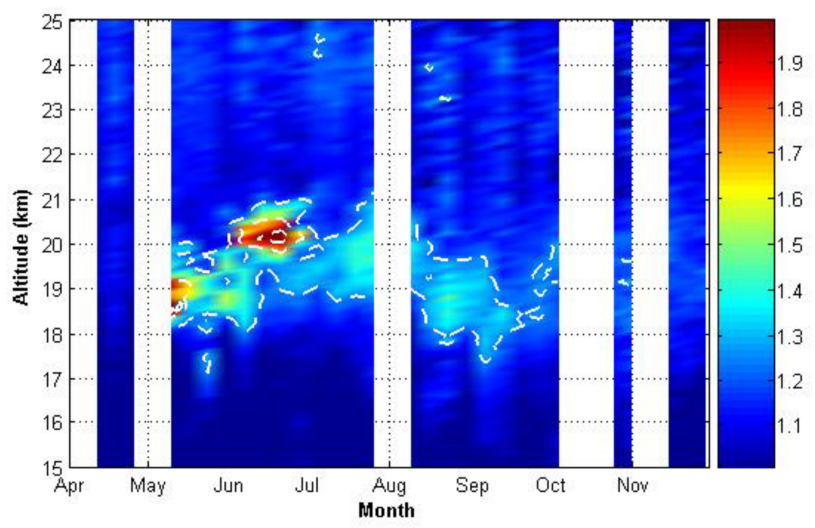

(b)

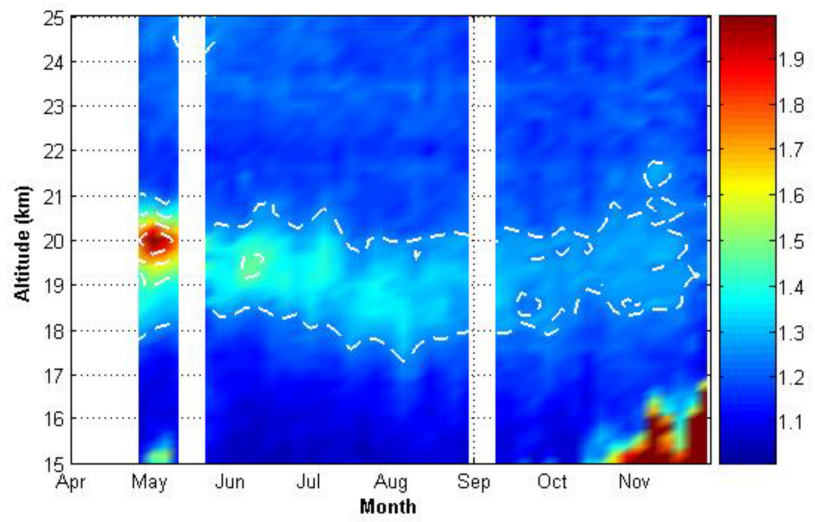

Figure 8. Time series of weekly averaged profiles of scattering ratio at $532 \mathrm{~nm}$ obtained from ground-based (a) and spaceborne (CALIOP, b) lidar observations over Reunion Island between April and December 2015. The scattering ratios from CALIOP have been averaged within $\pm 5^{\circ}$ latitude and $\pm 50^{\circ}$ longitude (extending from Africa to Australia) around Reunion Island.

this study could also be due to horizontal resolution or different measurement techniques. Unlike satellite experiments that allow for global observations, a ground-based lidar system is able to derive aerosol characteristics at a specific location. OMPS views the Earth's limb looking backward along the orbit track of approximately $125 \mathrm{~km}$ with a horizontal resolution of $50 \mathrm{~km}$. It is difficult for OMPS to detect with accuracy small amounts of aerosol at a local point with these weak vertical and horizontal resolutions. It is for this reason that the structure of the plume observed since July is not in agreement with the ground-based lidar. As we will discuss in more detail in Sect. 4, the dynamical context can induce inhomogeneity of the plume. As a consequence, this inhomogeneity of the plume could lead to incorrect identification of the volcanic aerosols by the satellites.

\subsubsection{In situ observations}

Four LOAC OPCs were launched over the Reunion Island site on 26 November 2014, 19 May 2015, 19 August 2015,
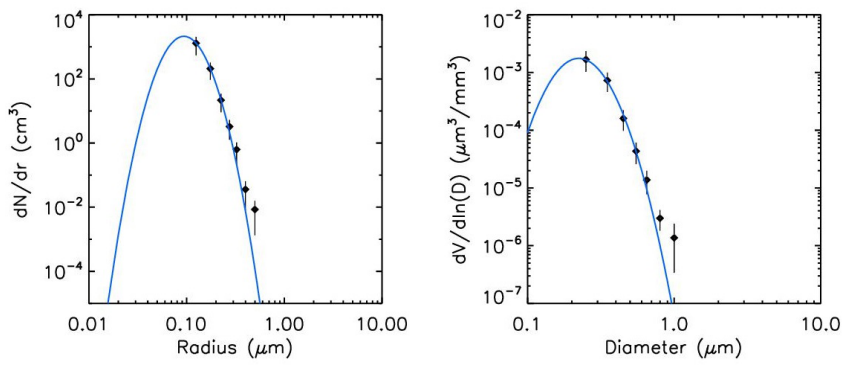

Figure 9. Number $(\mathrm{dN} / \mathrm{d} \ln (\mathrm{D}))$ and volume concentration $(\mathrm{dV} / \mathrm{d} \ln (\mathrm{D}))$ obtained from LOAC OPC observations on 19 May 2015 at 17:46 UTC over the Reunion site.

and 2 November 2016. SAOD $532 \mathrm{~nm}$ values were calculated following Mie theory from fits to the observed size distributions at each level. LOAC observations also reveal an increase by a factor of 2 in the SAOD on 19 May 2015 $\left(1.35 \times 10^{-2}\right)$. SAOD decreases to $8.4 \times 10^{-3}$ on $19 \mathrm{Au}-$ gust 2015 followed by a return to pre-eruption levels by November 2016 (Fig. 6). The overall evolution of SAOD derived from LOAC compares fairly well to OMPS and to lidar observations, accounting for error bars (Fig. 6). The $10 \mathrm{~s}$ sampling rate of the LOAC instrument and the ascent velocity of the balloon determine the vertical resolution. The difference observed between the daily lidar and the in situ data may be due to the $1 \mathrm{~min}$ averaging of the in situ data, which tends to smooth structure attributed to the volcanic aerosols.

Figure 9 illustrates the number $(\mathrm{dN} / \mathrm{d} \ln (\mathrm{D}))$ and volume $(\mathrm{dV} / \mathrm{d} \ln (\mathrm{D}))$ concentrations obtained from the LOAC OPC observations over the Reunion Island site on 19 May 2015 at 17:46 UTC. LOAC OPC observations reveal a size distribution with decreasing concentrations for particle sizes larger than $0.2 \mu \mathrm{m}$ (Fig. 9). The value of $0.2 \mu \mathrm{m}$ represents the lower bound of the LOAC size range, so the data may miss possible secondary modes for smaller particles (Wilson et al., 2008). Particle concentrations for sizes larger than $1 \mu \mathrm{m}$ are too low to be properly detected by the LOAC OPC and undoubtedly indicate a coarse mode. However, there is no clear evidence of a bimodal distribution; as observed during the first weeks after the eruption of Mt. Pinatubo, there is an intense second mode possibly consisting of volcanic ash (e.g., Russell et al., 1996). The shape of the size distribution obtained during the Calbuco event is similar to that obtained by Kravitz et al. (2011) for the Sarychev eruption. As suggested by Kravitz et al. (2011), we can also assume that the Calbuco eruption did not eject enough material to create a bimodal structure over Reunion Island.

The effective radius derived from the LOAC OPC on 19 May is $0.17 \pm 0.02 \mu \mathrm{m}$, indicating that the particles observed several weeks after the Calbuco eruption are quite small. Interestingly, Jégou et al. (2013) reported that the effective radius obtained during the Sarychev event ranged from 0.15 to $0.20 \mu \mathrm{m}$ more than 1 month after the erup- 


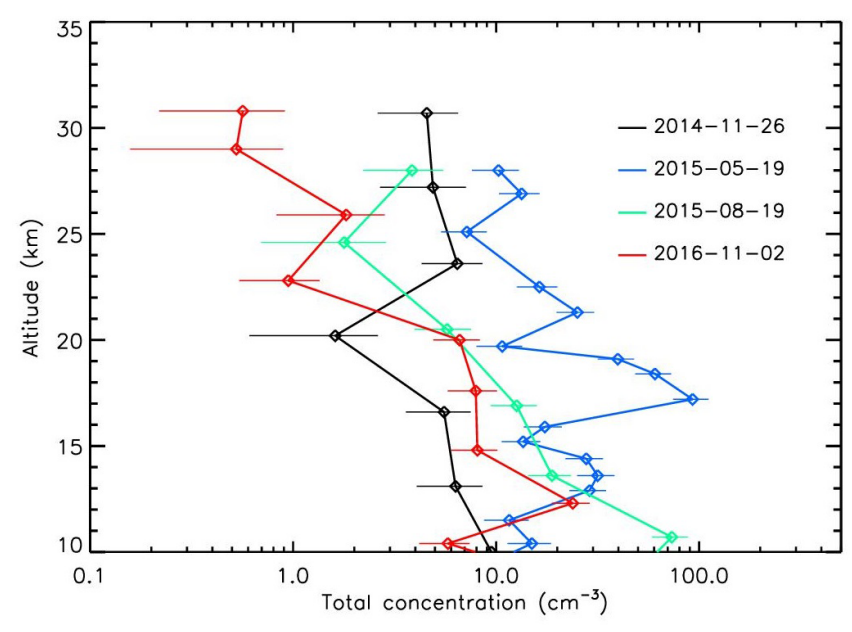

Figure 10. Total number concentration of aerosol $(0.2-50 \mu \mathrm{m})$ profiles obtained from LOAC OPC observations over Reunion on 26 November 2014 (black line), 19 May 2015 (blue line), 19 August 2015 (green line), and 2 November 2016 (red line).

tion, which is in agreement with the results of O'Neill et al. (2012). Therefore, both eruptions are comparable in terms of size distribution shape and effective radius. Russell et al. (1996) reported that in the month following the Pinatubo eruption the mean effective radius did not differ greatly from pre-eruption values (i.e., $0.17 \pm 0.07 \mu \mathrm{m}$ in their study), possibly because a large number of particles with sizes both smaller and larger than $0.17 \mu \mathrm{m}$ were injected (the latter consisting most likely of volcanic ash).

The integrated number of particles obtained over all 19 size classes from 0.2 to $50 \mu \mathrm{m}$ in diameter is presented in Fig. 10. A local aerosol concentration enhancement is detected in the lower stratosphere $(16.8-19 \mathrm{~km})$ over Reunion Island on 19 May 2015 at 17:46 UTC. A maximum concentration of about 150 particles $\mathrm{cm}^{-3}$ (total number of particles: $730 \pm 130$ particles, $\pm 1 \sigma$ ) is observed by the aerosol counter for particle sizes larger than $0.2 \mu \mathrm{m}$. Few in situ observations are available in tropical regions such as Reunion Island to provide a reference state of the background aerosol content. In comparison to the LOAC flight on 26 November 2014 at 14:42 UTC (5 months before the eruption), the aerosol number concentration observed on 19 May 2015 is $\sim 20$ times higher. Three months later, another LOAC OPC was launched over the Reunion Island site but the in situ profile only partially shows the volcanic aerosol layer because of a telemetry loss. The aerosol number concentration obtained on 19 August 2015 at 13:00 UTC over Reunion Island may reveal a tendency to return to concentration values observed before the eruption (Fig. 10), with a number concentration of 40 particles per $\mathrm{cm}^{3}$ in the lower stratosphere. This tendency is confirmed with the LOAC flight conducted on 2 November 2016 at 20:30 UTC with a total number concen-

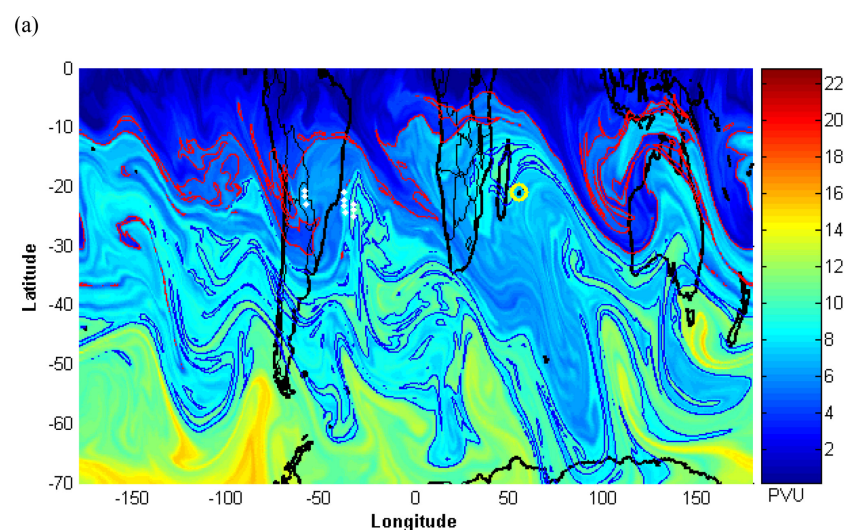

(b)

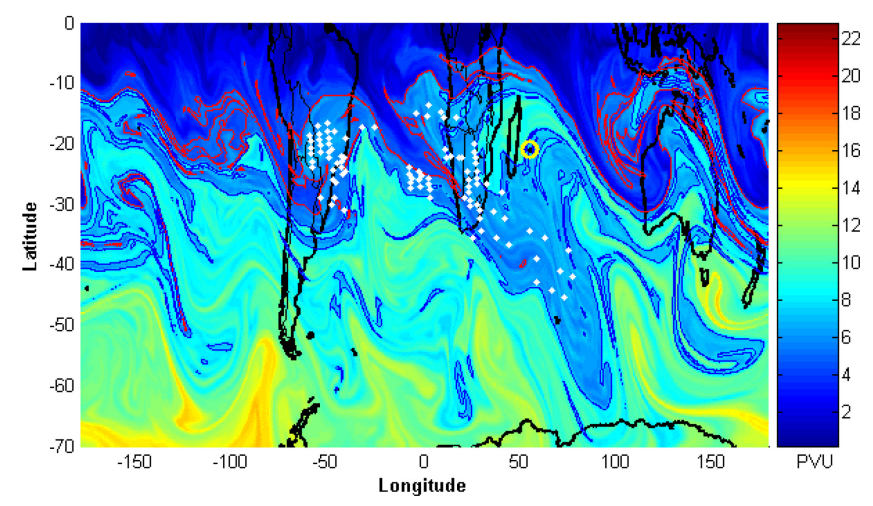

Figure 11. Advected PV map at the $400 \mathrm{~K}$ level obtained from the MIMOSA model (a) on 27 April 2015 and (b) on 1 May 2015. The positions of the subtropical barrier (red line) and a south dynamical barrier (blue line) are detected from the DyBAL code. The white dots represent the localization of the aerosol plume at $400 \mathrm{~K} \pm 5 \mathrm{~K}$ obtained from OMPS observations, while the yellow circles indicate the Reunion site.

tration close to 20 particles $\mathrm{cm}^{-3}$ in the lower stratosphere (Fig. 10).

The residence time of the aerosol particles in the stratosphere depends on the balance between the growth processes and the removal processes, which are likely to be controlled by the dynamical context. In the following section, we will discuss the influence of the dynamical activity on the variability in the volcanic aerosols over the Southern Hemisphere.

\section{Dynamical modulation of the aerosol plume}

\subsection{Long-range transport}

In order to analyze isentropic transport, the high-resolution MIMOSA model has been used to produce a continuous evolution of PV fields for the period from 1 April 2015 to 31 August 2015. Four advected PV maps derived for the $400 \mathrm{~K}$ isentropic level from the MIMOSA model together with dynamical barrier locations derived from the DyBAL 

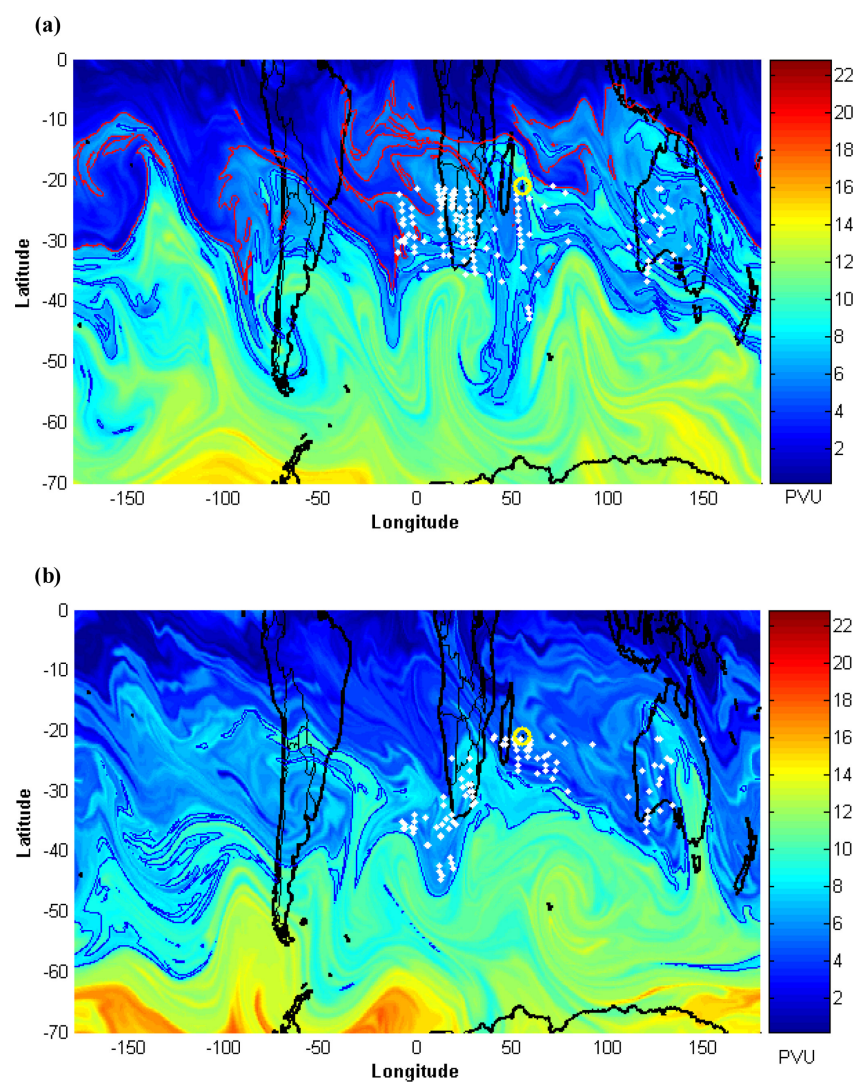

Figure 12. Same as Fig. 11 but for (a) 19 May 2015 and (b) 3 June 2015.

code are superimposed in Figs. 11 and 12. The localization of the volcanic aerosol plume obtained from OMPS observations at the $400 \mathrm{~K} \pm 5 \mathrm{~K}$ isentropic level is also superimposed (Figs. 11 and 12). On 24 April 2015, significant wave activity is observed, leading to a fairly mixed surf zone in the $20-60^{\circ} \mathrm{S}$ latitude band (not shown). The Calbuco plume is situated inside the surf zone and the plume was mixed equatorward. On 27 April 2015, the subtropical and midlatitude barrier are detected following the Nakamura formalism (described in Sect. 2.3) around $15^{\circ} \mathrm{S}$ (red line, Fig. 11) and $40^{\circ} \mathrm{S}$ (blue line) latitude, respectively, limiting the geographical extent of the plume (Fig. 11a). Figure 11a clearly shows that the air masses containing aerosols cannot move beyond the south of Brazil because of the presence of the subtropical barrier. On 1 May 2015, the air masses were confined between the two dynamical barriers located on average at $25^{\circ} \mathrm{S}$ (red line, Fig. 11b) and $40^{\circ} \mathrm{S}$ (blue line, Fig.11b) latitude, respectively. The air masses were advected eastward between South Africa and Madagascar following the wave shape of the barrier, which is consistent with the OMPS observations near South Africa (Fig. 11b). The subtropical barrier previously located at $25^{\circ} \mathrm{S}$ (red line, Fig. 11b) moved northward crossing South Africa. The air masses containing aerosol previously situated on the south side of Madagascar were trans- ported northward and eastward following the displacement of the barrier and reached the Reunion Island site.

On 19 May 2015 (Fig. 12a), the volcanic aerosol plume was confined between the two dynamical barriers and advected eastward. At this stage, the presence of the subtropical barrier and the polar vortex seems to constrain the Calbuco plume inducing its transport eastward. Between the end of May and the beginning of June, the subtropical barrier dissipated while the edge of the polar vortex was around $\sim 40^{\circ} \mathrm{S}$ (blue line, Fig. 12b). The OMPS observations reveal that the majority of the plume was located over the southern African and the Indian Ocean region in June (Fig. 12b). On the following months of July and August, the polar vortex is clearly identified at $60^{\circ} \mathrm{S}$ (blue line, Fig. 12b), which is a classical pattern for the austral winter.

This present study discusses only the transport of the volcanic aerosol plume at the $400 \mathrm{~K}$ isentropic level (isentropic level at which the Calbuco plume is detected at Reunion). Figures 4 and 5 reveal that the meridional transport of the plume occurred between 12 and $20 \mathrm{~km}$. In particular, Fig. $5 \mathrm{~b}$ also reveals the possibility of the Calbuco aerosol plume penetrating the polar vortex at the end of August 2015. This assumption seems to be consistent with reports by Ivy et al. (2017) and Solomon et al. (2016). Based on the SDWACCM (Specified Dynamics-Whole Atmosphere Community Climate Model) and balloon observations at Syowa $\left(69^{\circ} \mathrm{S}, 34.58^{\circ} \mathrm{E}\right)$, Solomon et al. (2016) discussed the impact of the Calbuco plume on the deepest Antarctic ozone depletion observed in October 2015. They reveal that the integrated additional Antarctic ozone column losses averaged over the polar cap are between 5 and 13 DU following the Calbuco eruption. Through the use of the FR-WACCM (freerunning Whole Atmosphere Community Climate Model), Ivy et al. (2017) show that the forced response to the eruption of Calbuco was an increase in the size of the ozone hole by $4.5 \times 10^{6} \mathrm{~km}^{2}$.

\subsection{Removal processes}

As discussed above, in the lower stratosphere distributions of the aerosols are modulated (or mostly driven) by isentropic transport. However, particle removal processes should be considered. As reported by Kremser et al. (2016), aerosol in the vicinity of the tropopause can be transported into the troposphere by a variety of mechanisms. Hamill et al. (1997) reported that stratosphere-troposphere exchange (STE) on isentropic surfaces due to Rossby wave activity can be considered a significant dynamical process for the removal of stratospheric aerosols. Depending on the strength of the Brewer-Dobson circulation, stratospheric materials such as aerosols can be rapidly transported from the tropics to high latitudes (Dhomse et al., 2006, 2014). Based on semi-Lagrangian and analyzed winds from ECMWF, Chen et al. (1995) investigated the extratropical STE on isentropic surfaces that intersect the tropopause. Above $340 \mathrm{~K}$ they 
found that STE exhibits a strong annual cycle in which very little STE takes place in the winter hemisphere, but significant STE occurs in the summer hemisphere, particularly in the northern summer. The weak STE in the winter hemisphere is mainly due to the barrier effect of the strong PV gradient at the tropopause (Chen et al., 1995). Through the use of 10 years of lidar observations at Pasadena $\left(34^{\circ} \mathrm{N}, 118^{\circ} \mathrm{W}\right.$; California), Menzies and Tratt. (1995) found a clear link between the aerosol optical properties in UT-LS and the active extratropical STE processes occurring in the winter and early spring. The calculated stratospheric mass extrusion rate is consistent with a 45-day lifetime of lower stratospheric aerosols during this part of the year, which implies that extratropical STE is a significant sink for stratospheric aerosols (Menzies and Tratt, 1995). Given the potential of an STE event to impact stratospheric aerosol loading, we cannot exclude its contribution (even though small) to the stratospheric aerosol loading at Reunion Island.

Dhomse et al. (2014), using a CCM (UM-UKCA), discussed the influence of STE events on the budget of the stratospheric aerosols. In particular, they suggested that a general overestimation of STE in global composition climate models could lead to the overestimated removal of aerosols from the stratosphere into the troposphere. Through the use of the ULAQ-CCM, Pitari et al. (2016b) show that the efficiency of STE depends on large-scale transport following the down-welling branch of the Brewer-Dobson circulation together with gravitational settling. The long-range transport of a volcanic plume is less likely to be isentropic due to the sedimentation of ash or other large particles (with any accommodated sulfur) within the plume. The modulation of the plume over Reunion Island could be caused by particle removal processes, such as sedimentation (considered as the primary loss mechanism of stratospheric aerosol), or through the dilution of the stratospheric plume (Hamill et al, 1997; Rasch et al., 2008). Sedimentation is an effective removal mechanism for particles that survive long enough in the stratosphere to grow to larger sizes (Hamill et al., 1997).

We note the potential role of removal processes in the initial dispersion of volcanic aerosols, particularly co-emitted ultrafine ash particles, but do not explore this effect here. Highlighting the removal processes from Figs. 7 and 8 is somewhat complicated by the transience in plume altitudes, especially in the lidar local data. The potential role of removal processes in the evolution of the plume requires further investigation and will form the basis for a forthcoming study.

\section{Summary and conclusion}

The long-range transport of the volcanic aerosol produced following the Calbuco eruption has been examined. The analysis focuses on the dynamical context that led to the spread of the aerosol plume over the Indian Ocean between April 2015 and November 2016. The transport of the volcanic aerosols to the Indian Ocean was investigated by combining satellite (CALIOP, IASI, OMPS) and ground-based experiments (optical particle counter (LOAC) and lidar) in addition to numerical tools (the DyBAL code and the high-resolution MIMOSA model).

The amount of $\mathrm{SO}_{2}$ injected into the atmosphere during the Calbuco eruption has been quantified using IASI observations. $\mathrm{SO}_{2}$ mass emitted by the Calbuco eruption was about 2 times lower than for the moderate Northern Hemisphere eruption of Sarychev in June 2009, but had a similar $\mathrm{SO}_{2} e-$ folding time (Jégou et al., 2013; Kravitz et al., 2011). It is found from CALIOP observations that the Calbuco aerosol layer was observable in the lower stratosphere between 18 and $21 \mathrm{~km}$ and spread exclusively in the Southern Hemisphere. OMPS observations reveal that the Calbuco plume reached the Indian Ocean 2 weeks after the eruption. It is shown from ground-based observations deployed at Reunion Island that SAOD increased by a factor of $\sim 2$ by the beginning of May 2015 and decreased afterward, returning to preeruption values by November 2016. The aerosol $e$-folding time is estimated to be $\sim 90$ days, close to the $\sim 80$ days reported for the Sarychev eruption (Jégou et al., 2013). Though the various datasets agree in terms of aerosol signal intensity, we report significant differences for the plume height and its variability, possibly as a result of the different observation geometries, resolutions, and spatial scales inherent in each instrument.

In situ measurements by the LOAC OPC have pointed out the impact of the Calbuco eruption on the lower stratospheric aerosol content over the Reunion Island site. Aerosol number concentrations were 20 times higher than the values observed before and 1 year after the eruption. On May 2015, the volcanic aerosol was characterized by an effective radius of $0.16 \pm 0.02 \mu \mathrm{m}$ and a unimodal lognormal size distribution above $250 \mathrm{~nm}$ in diameter. These microphysical characteristics are in agreement with previous studies focusing on the Sarychev eruption (Kravitz et al., 2011; Jégou et al., 2013).

Through the use of the MIMOSA model and the DyBAL code, it was clearly identified that the eastward transport of the volcanic aerosols occurred mainly in the form of planetary-scale tongues. In particular, the combination of MIMOSA and DyBAL simulations revealed that the transport of the volcanic aerosol plume eastward was confined between the subtropical barrier and midlatitude (polar vortex) dynamical barriers, within which most of the zonal transport took place. Our results support the assumption that the processes explaining the structure of the plume over the Southern Hemisphere had mainly a dynamical origin. Thus, the fluctuation of the subtropical barrier induced transient aerosol layers above Reunion Island and an inhomogeneous distribution of the plume between May and July 2015. The present study also supports the hypothesis that the modulation of a volcanic plume results from a contribution of both dynamical and microphysical processes. Fully understanding 
the contribution of the microphysical processes to the evolution of the volcanic plume over the Southern Hemisphere requires further investigation. This will be examined in a forthcoming study.

Data availability. The data used for this study are available and open access by request to scientist mentioned hereafter: LOAC (jean.baptiste.renard@cnrs-orleans.fr), LiDAR measurements (guillaume.payen@univ-reunion.fr); CALIOP (jeanpaul.vernier@nasa.gov); IASI (lclariss@ulb.ac.be); the OMPS data used in this study are available at: https://ozoneaq.gsfc.nasa.gov/.

Competing interests. The authors declare that they have no conflict of interest.

Acknowledgements. This work is supported by the Labex Étude des géofluides et des VOLatils-Terre, Atmosphère et Interfaces - Ressources et Environnement (VOLTAIRE; ANR-10-LABX100-01). This study is integrated and supported by the LEFE project SATORI (Stratospheric Aerosols in the Tropics Observed from Reunion Island). The authors thank the LPC2E and UMS balloon launching team for their technical collaboration. We would especially like to thank the staff of the team working on the lidar systems at the Maïdo observatory. Lieven Clarisse is a research associate with the Belgian FNRS-F.R.S. The authors also thank the CALIOP team and Jean-Paul Vernier for processing and providing data. OMPS observations were obtained from the OMPS website (https://ozoneaq.gsfc.nasa.gov/). We are also grateful to the CCUR team for the use of the TITAN supercomputer. We also thank Duncan Fairlie for his contribution to improving the English of this paper.

Edited by: Anja Schmidt

Reviewed by: Vladislav Gerasimov, Daniele Visioni, and one anonymous referee

\section{References}

Arfeuille, F., Luo, B. P., Heckendorn, P., Weisenstein, D., Sheng, J. X., Rozanov, E., Schraner, M., Brönnimann, S., Thomason, L. W., and Peter, T.: Modeling the stratospheric warming following the Mt. Pinatubo eruption: uncertainties in aerosol extinctions, Atmos. Chem. Phys., 13, 11221-11234, https://doi.org/10.5194/acp-13-11221-2013, 2013.

Baray, J.-L., Courcoux, Y., Keckhut, P., Portafaix, T., Tulet, P., Cammas, J.-P., Hauchecorne, A., Godin Beekmann, S., De Mazière, M., Hermans, C., Desmet, F., Sellegri, K., Colomb, A., Ramonet, M., Sciare, J., Vuillemin, C., Hoareau, C., Dionisi, D., Duflot, V., Vérèmes, H., Porteneuve, J., Gabarrot, F., Gaudo, T., Metzger, J.-M., Payen, G., Leclair de Bellevue, J., Barthe, C., Posny, F., Ricaud, P., Abchiche, A., and Delmas, R.: Maïdo observatory: a new high-altitude station facility at Reunion Island $\left(21^{\circ} \mathrm{S}, 55^{\circ} \mathrm{E}\right)$ for long-term atmospheric remote sensing and in situ measurements, Atmos. Meas. Tech., 6, 2865-2877, https://doi.org/10.5194/amt-6-2865-2013, 2013.

Bauman, J. J., Russell, P. B., Geller, M. A., and Hamill, P.: A stratospheric aerosol climatology from SAGE II and CLAES measurements: 2. Results and comparisons, 1984-1999, J. Geophys. Res., 108, 4383, https://doi.org/10.1029/2002JD002993, 2003.

Bekki, S.: On the possible role of aircraft-generated soot in the middle latitude ozone depletion, J. Geophys. Res., 102, 1075110758, 1997.

Bencherif, H., Portafaix, T., Baray, J. L., Morel, B., Baldy, S., Leveau and J., and Diab, R.: LIDAR observations of lower stratospheric aerosols over South Africa linked to large scale transport across the southern subtropical barrier, J. Atmos. Sol.-Terr. Phys., 65, 707-715, 2003.

Bencherif, H., Amraoui, L. E., Semane, N., Massart, S., Charyulu, D. V., Hauchecorne, A., and Peuch, V. H., Examination of the 2002 major warming in the southern hemisphere using groundbased and Odin/SMR assimilated data: stratospheric ozone distributions and tropic/mid-latitude exchange, Can. J. Phys., 85, 1287-1300, 2007.

Bluth, G. J. S., Doiron, S. D., Schnetzler, C. C., Krueger, A. J., and Walter, L. S.: Global tracking of the $\mathrm{SO}_{2}$ clouds from the June 1991 Mount Pinatubo eruptions, Geophys. Res. Lett., 19, 151154, https://doi.org/10.1029/91GL02792, 1992.

Borrmann, S., Solomon, S., Dye, J. E., Baumgardner, D., Kelly, K. K., and Chan, K. R.: Heterogeneous reactions on stratospheric background aerosols, volcanic sulfuric acid droplets, and type I PSCs: The effects of temperature fluctuations and differences in particle phase, J. Geophys. Res., 102, 3639-3648, 1997.

Bourassa, A. E., Degenstein, D. A., Elash, B. J., and Llewellyn, E. J.: Evolution of the stratospheric aerosol enhancement following the eruptions of Okmok and Kasatochi: OdinOSIRIS measurements, J. Geophys.Res., 115, D00L03, https://doi.org/10.1029/2009JD013274, 2010.

Bourassa, A. E., McLinden, C. A., Bathgate, A. F., Elash,B. J., and Degenstein, D. A.: Precision estimate for OdinOSIRIS limb scatter retrievals, J. Geophys. Res., 117, D04303, https://doi.org/10.1029/2011JD016976, 2012.

Canty, T., Mascioli, N. R., Smarte, M. D., and Salawitch, R. J.: An empirical model of global climate - Part 1: A critical evaluation of volcanic cooling, Atmos. Chem. Phys., 13, 3997-4031, https://doi.org/10.5194/acp-13-3997-2013, 2013.

Carn, S., Clarisse, L., and Prata, A. J.: Multi-decadal satellite measurements of global volcanic degassing, J. Volcanol. Geotherm. Res., 311, 99-134, 2016.

Chen, P., Holton, J. R., O’Neill, A., and Swinbank, R.: Isentropic mass exchange between the Tropics and extratropics in the stratosphere, J. Atmos. Sci., 51, 3006-3018, 1994.

Chen, P.: Isentropic cross-tropopause mass exchange in the extratropics, J. Geophys. Res.-Atmos., 100, 16661-16673, 1995.

Clarisse, L., Coheur, P. F., Prata, A. J., Hurtmans, D., Razavi, A., Phulpin, T., Hadji-Lazaro, J., and Clerbaux, C.: Tracking and quantifying volcanic $\mathrm{SO}_{2}$ with IASI, the September 2007 eruption at Jebel at Tair, Atmos. Chem. Phys., 8, 7723-7734, https://doi.org/10.5194/acp-8-7723-2008, 2008.

Clarisse, L., Hurtmans, D., Clerbaux, C., Hadji-Lazaro, J., Ngadi,Y., and Coheur, P.-F.: Retrieval of sulphur dioxide from the infrared atmospheric sounding interferometer (IASI), Atmos. 
Meas. Tech., 5, 581-594, https://doi.org/10.5194/amt-5-5812012, 2012

Clarisse, L., Coheur, P.-F., Theys, N., Hurtmans, D., and Clerbaux, C.: The 2011 Nabro eruption, a $\mathrm{SO}_{2}$ plume height analysis using IASI measurements, Atmos. Chem. Phys., 14, 3095-3111, https://doi.org/10.5194/acp-14-3095-2014, 2014.

Clerbaux, C., Boynard, A., Clarisse, L., George, M., Hadji-Lazaro, J., Herbin, H., Hurtmans, D., Pommier, M., Razavi, A., Turquety, S., Wespes, C., and Coheur, P.-F.: Monitoring of atmospheric composition using the thermal infrared IASI/MetOp sounder, Atmos. Chem. Phys., 9, 6041-6054, https://doi.org/10.5194/acp-96041-2009, 2009.

Dhomse, S., Weber, M., Wohltmann, I., Rex, M., and Burrows, J. P.: On the possible causes of recent increases in northern hemispheric total ozone from a statistical analysis of satellite data from 1979 to 2003, Atmos. Chem. Phys., 6, 1165-1180, https://doi.org/10.5194/acp-6-1165-2006, 2006.

Dhomse, S. S., Emmerson, K. M., Mann, G. W., Bellouin, N., Carslaw, K. S., Chipperfield, M. P., Hommel, R., Abraham, N. L., Telford, P., Braesicke, P., Dalvi, M., Johnson, C. E., O'Connor, F., Morgenstern, O., Pyle, J. A., Deshler, T., Zawodny, J. M., and Thomason, L. W.: Aerosol microphysics simulations of the Mt. Pinatubo eruption with the UM-UKCA composition-climate model, Atmos. Chem. Phys., 14, 1122111246, https://doi.org/10.5194/acp-14-11221-2014, 2014.

Fairlie, T. D., Vernier, J.-P., Natarajan, M., and Bedka, K. M.: Dispersion of the Nabro volcanic plume and its relation to the Asian summer monsoon, Atmos. Chem. Phys., 14, 7045-7057, https://doi.org/10.5194/acp-14-7045-2014, 2014.

Froyd, K. D., Murphy, D. M., Sanford, T. J., Thomson, D. S., Wilson, J. C., Pfister, L., and Lait, L.: Aerosol composition of the tropical upper troposphere, Atmos. Chem. Phys., 9, 4363-4385, https://doi.org/10.5194/acp-9-4363-2009, 2009.

Fussen, D., Vanhellemont, F., and Bingen, C.: Evidence of transport, sedimentation and coagulation mechanisms in the relaxation of post-volcanic stratospheric aerosols, Ann. Geophys., 19, 1157-1162, https://doi.org/10.5194/angeo-19-1157-2001, 2001.

Godin, S., Marchand, M., and Hauchecorne, A.: Influence of Artic polar ozone depletion on the lower stratosperic ozone amounts at Haute-Provence Observatory $\left(44^{\circ} \mathrm{N}, 60^{\circ} \mathrm{E}\right)$, J. Geophys. Res, 107, 107D20, https://doi.org/10.1029/2001JD000516, 2002.

Gorkavyi, N., Rault, D. F., Newman, P. A., Silva, A. M. d., an Dudorovd A. E.: New stratospheric dust belt due to the Chelyabinsk bolide, Geophys. Res. Lett., 40, 47284733, https://doi.org/10.1002/grl.50788, 2013.

Grant, W. B., Browell, E. V., Fishman, J., Brackett, V. G., Veiga, R. E., Nganga, D., and Long, C. S.: Aerosol-associated changes in tropical stratospheric ozone following the eruption of Mount Pinatubo, J. Geophys. Res.-Atmos., 99, 8197-8211, 1994.

Grant, W. B., Browell, E. V., Long, C. S., Stowe, L. L., Grainger, R. G., and Lambert, A.: Use of volcanic aerosols to study the tropical stratospheric reservoir, J. Geophys. Res., 101, 3973-3988, 1996.

Guo, S., Bluth, G. J., Rose, W. I., Watson, I. M., and Prata, A. J.: Reevaluation of $\mathrm{SO}_{2}$ release of the 15 June 1991 Pinatubo eruption using ultraviolet and infrared satellite sensors, Geochem. Geophy. Geosy., 5, Q04001, https://doi.org/10.1029/2003GC000654, 2004.
Hamill, P., Jensen, E. J., Russell, P. B., and Bauman, J. J.: The life cycle of stratospheric aerosol particles, B. Am. Meteorol. Soc., 78, 1395-1410, https://doi.org/10.1175/15200477(1997)078<C1395:TLCOSA>E2.0.CO;2, 1997.

Hauchecorne, A.: Ether, Service Arletty, Atmospheric Model Description, ETH-ACR-AR-DM-001, 22 pp., 1998.

Hauchecorne, A., Godin, S., Marchand, M., Heese, B., and Souprayen, C.: Quantification of the transport of chemical constituents from the polar vortex to midlatitudes in the lower stratosphere using the high-resolution advection model MIMOSA and effective diffusivity, J. Geophys. Res.-Atmos., 107, 1-13, 2002.

Heese, B., Godin, S., and Hauchecorne, A.: Airborne lidar measurements of ozone filaments during METRO-A validation of PV advection model MIMOSA, J. Geophys. Res, 106, 2001120024, 2001.

Hermann, M., Heintzenberg, J., Wiedensohler, A., Zahn, A., Heinrich, G., and Brenninkmeijer, C. A. M.: Meridional distributions of aerosol particle number concentrations in the upper troposphere and lower stratosphere obtained by Civil Aircraft for Regular Investigation of the Atmosphere Based on an Instrument Container (CARIBIC) flights, J. Geophys. Res., 108, 4114, https://doi.org/10.1029/2001JD001077, 2003.

Hitchman, M. H., McKay, M., and Trepte, C. R.: A climatology of stratospheric aerosol, J. Geophys. Res., 99, 20689-20700, 1994.

Hofmann, D., Barnes, J., O’Neill, M., Trudeau, M., and Neely, R.: Increase in background stratospheric aerosol observed with lidar at Mauna Loa Observatory and Boulder, Colorado, Geophys. Res. Lett., 36, L15808, https://doi.org/10.1029/2009GL039008, 2009.

Hommel, R., Timmreck, C., Giorgetta, M. A., and Graf, H. F.: Quasi-biennial oscillation of the tropical stratospheric aerosol layer, Atmos. Chem. Phys., 15, 5557-5584, https://doi.org/10.5194/acp-15-5557-2015, 2015.

Ivy, D. J., Solomon, S., Kinnison, D., Mills, M. J., Schmidt, A., and Neely III, R. R.: The influence of the Calbuco eruption on the 2015 Antarctic ozone hole in a fully coupled chemistry-climate model, Geophys. Res. Lett., 44, 2556-2561, https://doi.org/10.1002/2016GL071925, 2017.

Jäger, H. and Deshler, T.: Lidar backscatter to extinction, mass and area conversions for stratospheric aerosols based on midlatitude balloonborne size distribution measurements, Geophys. Res. Lett., 29, 1929, https://doi.org/10.1029/2002GL015609, 2002.

Jaross, G., Chen, G., Kowitt, M., Warmer, J., Xu, P., Kelly, T., and Flittner, D.: Suomi NPP OMPS Limb Profiler initial sensor performance assessment, in: SPIE asia-Pacific Remote Sensing, International Society for Optics and Photonics, 852805-852805, 2012.

Jumelet, J., Bekki, S., Seifert, P., Montoux, N., Vernier, J.-P., and Pelon, J.: Microphysical modeling of a midlatitude "polar stratospheric cloud" event: Comparisons against multiwavelength ground-based and spaceborne lidar data, J. Geophys. Res., 114, D00H03, https://doi.org/10.1029/2009JD011776, 2009.

Jégou, F., Berthet, G., Brogniez, C., Renard, J.-B., François, P., Haywood, J. M., Jones, A., Bourgeois, Q., Lurton, T., Auriol, F., Godin-Beekmann, S., Guimbaud, C., Krysztofiak, G., Gaubicher, B., Chartier, M., Clarisse, L., Clerbaux, C., Balois, J. Y., Verwaerde, C., and Daugeron, D.: Stratospheric aerosols from the Sarychev volcano eruption in the 2009 Arctic summer, At- 
mos. Chem. Phys., 13, 6533-6552, https://doi.org/10.5194/acp13-6533-2013, 2013.

Junge, C. E., Chagnon, C. W., and Manson, J. E.: Stratospheric aerosols, J. Meteorol., 18, 81-108, 1961.

Kinnison, D. E., Grant, K. E., Connell, P. S., Rotman, D. A., and Wuebbles, D. J.: The chemical and radiative effects of the Mount Pinatubo eruption, J. Geophys. Res., 99, 25705-25731, https://doi.org/10.1029/94JD02318, 1994.

Klett, J. D.: Stable analytical inversion solution for processing lidar returns, Appl. Opt., 20, 211-220, 1981.

Kravitz, B., Robock, A., and Bourassa, A.: Negligible climatic effects from the 2008 Okmok and Kasatochi volcanic eruptions, J. Geophys. Res., 115, D00L05, https://doi.org/10.1029/2009JD013525, 2010.

Kravitz, B., Robock, A., Bourassa, A., Deshler, T., Wu, D., Mattis, I., Finger, F., Hoffmann, A., Ritter, C., Bitar, L., Duck, T. J., and Barnes, J. E.: Simulation and observations of stratospheric aerosols from the 2009 Sarychev volcanic eruption, J. Geophys. Res., 116, D18211, https://doi.org/10.1029/2010JD015501, 2011.

Kremser, S., Thomason, L. W., Hobe, M., et al.: Stratospheric aerosol - Observations, processes, and impact on climate, Rev. Geophys., 54, 278-335, 2016.

Kristiansen, N. I., Prata, A. J., Stohl, A., and Carn, S. A.: Stratospheric volcanic ash emissions from the 13 February 2014 Kelut eruption, Geophys. Res. Lett., 42, 588-596, https://doi.org/10.1002/2014GL062307, 2015.

Krotkov, N. A., Schoeberl, M. R., Morris, G. A., Carn, S., and Yang, K.: Dispersion and lifetime of the $\mathrm{SO}_{2}$ cloud from the August 2008 Kasatochi eruption, J. Geophys. Res., 115, D00L20, https://doi.org/10.1029/2010jd013984, 2010.

Labitzke, K. and McCormick, M.: Stratospheric temperature increases due to Pinatubo aerosols, Geophys. Res. Lett., 19, 207210, 1992.

Lurton, T., Renard, J.-B., Vignelles, D., Jeannot, M., Akiki, R., Mineau, J.-L., and Tonnelier, T.: Light scattering at small angles by atmospheric irregular particles: modelling and laboratory measurements, Atmos. Meas. Tech., 7, 931-939, https://doi.org/10.5194/amt-7-931-2014, 2014.

McCormick, M. P., Thomason, L. W., and Trepte, C. R.: Atmospheric effects of the Mt Pinatubo eruption, Nature, 373, 399404, 1995.

Menzies, R. T. and Tratt, D. M.: Evidence of seasonally dependent stratosphere-troposphere exchange and purging of lower stratospheric aerosol from a multiyear lidar data set, J. Geophys. Res.Atmos., 100, 3139-3148, 1995.

Morel, B., Bencherif, H., Keckhut, P., Portafaix, T., Hauchecorne, A., and Baldy, S.: Fine-scale study of a thick stratospheric ozone lamina at the edge of the southern subtropical barrier: 2. Numerical simulations with coupled dynamics models, J. Geophys. Res.Atmos., 110, D17101, https://doi.org/10.1029/2004JD005737, 2005.

Mossop, S. C.: Stratospheric particles at $20 \mathrm{~km}$ altitude, Geochem. Cosmochim. Ac., 29, 201-207, 1965.

Murphy, D. M., Thomson, D. S., and Mahoney, M. J.: In situ measurements of organics, meteoritic material, mercury, and other elements in aerosols at 5 to 19 kilometers, Science, 282, 16641669, 1998.
Nair, P. J., Godin-Beekmann, S., Froidevaux, L., Flynn, L. E., Zawodny, J. M., Russell III, J. M., Pazmiño, A., Ancellet, G., Steinbrecht, W., Claude, H., Leblanc, T., McDermid, S., van Gijsel, J. A. E., Johnson, B., Thomas, A., Hubert, D., Lambert, J.-C., Nakane, H., and Swart, D. P. J.: Relative drifts and stability of satellite and ground-based stratospheric ozone profiles at NDACC lidar stations, Atmos. Meas. Tech., 5, 1301-1318, https://doi.org/10.5194/amt-5-1301-2012, 2012.

Nakamura, N.: Two-dimensional mixing, edge formation, and permeability diagnosed in an area coordinate, J. Atmos. Sci., 53, 1524-1537, 1996.

Neely, R. R., Yu, P., Rosenlof, K. H., Toon, O. B., Daniel, J. S., Solomon, S., and Miller, H. L.: The contribution of anthropogenic $\mathrm{SO}_{2}$ emissions to the Asian tropopause aerosol layer, J. Geophys. Res., 119, 1571-1579, https://doi.org/10.1002/2013JD020578, 2014.

O’Neill, N. T., Perro, C., Saha, A., Lesins, G., Duck, T. J., Eloranta, E. W., and Bourassa, A.: Properties of Sarychev sulphate aerosols over the Arctic, J. Geophys. Res.-Atmos., 117, D04203, https://doi.org/10.1029/2011JD016838, 2012.

Pitari, G., Cionni, I., Di Genova, G., Visioni, D., Gandolfi, I., and Mancini, E.: Impact of stratospheric volcanic aerosols on age-ofair and transport of long-lived species, Atmosphere, 7, 149 pp., 2016a.

Pitari, G., Di Genova, G., Mancini, E., Visioni, D., Gandolfi, I., and Cionni, I.: Stratospheric aerosols from major volcanic eruptions: a composition-climate model study of the aerosol cloud dispersal and e-folding time, Atmosphere, 7, 75 pp., $2016 \mathrm{~b}$.

Portafaix, T., Morel, B., Bencherif, H., Baldy, S., GodinBeekmann, S., and Hauchecorne, A.: Fine-scale study of a thick stratospheric ozone lamina at the edge of the southern subtropical barrier, J. Geophys. Res.-Atmos., 108, D64196, https://doi.org/10.1029/2002JD002741, 2003.

Pueschel, R. F., Snetsinger, K. G., Russell, P. B., Kinne, S. A., and Livingston, J. M.: The effects of the 1991 Pinatubo volcanic eruption on the optical and physical properties of stratospheric aerosols, Proceedings of IRS92: Current Problems in Atmospheric Radiation, 183-186, 1992.

Rasch, P. J., Tilmes, S., Turco, R. P., Robock, A., Oman, L., Chen, C. C. J., and Garcia, R. R., An overview of geoengineering of climate using stratospheric sulphate aerosols, Philos. T. R. Soc. Lond., 366, 4007-4037, 2008.

Randel, W. J., Gille, J. C., Roche, A. E., Kumer, J. B., Mergenthaler, J. L., Waters, J. W., and Lahoz, W. A.: Stratospheric transport from the tropics to middle latitudes by planetary-wave mixing, Nature, 365, 533-535, 1993.

Rault, D. F. and Loughmann, R. P.: The OMPS Limb Profiler environmental data record algorithm theoretical basis document and expected performance, IEEE T. Geosci. Remote, 51, 2505-2527, 2013.

Renard, J. B., Dulac, F., Berthet, G., Lurton, T., Vignelles, D., Jégou, F., Tonnelier, T., Thaury, C., Jeannot, M., Couté, B., Akiki, R., Verdier, N., Mallet, M., Gensdarmes, F., Charpentier, P., Duverger, V., Dupont, J.V., Mesmin, S., Elias, T., Crenn, V., Sciare, J., Giacomoni, J., Gobbi, M., Hamonou, E., Olafsson, H., Dagsson-Waldhauserova, P., Camy-Peyret, C., Mazel, C., Décamps, T., Piringer, M., Surcin, J., and Daugeron, D.: LOAC: a small aerosol optical counter/sizer for ground-based and balloon measurements of the size distribution and nature of atmo- 
spheric particles - Part 1: Principle of measurements and intercomparison campaigns, Atmos. Meas. Tech., 9, 1721-1742, https://doi.org/10.5194/amt-9-1721-2016, 2016.

Ridley, D. A., Solomon, S., Barnes, J. E., Burlakov, V. D., Deshler, T., Dolgii, S. I., Herber, A. B., Nagai, T., Neely III, R. R., Nevzorov, A. V., Ritter, C., Sakai, T., Santer, B. D., Sato, M., Schmidt, A., Uchino, O., and Vernier, J. P.: Total volcanic stratospheric aerosol optical depths and implications for global climate change, Geophys. Res. Lett., 41, 7763-7769, https://doi.org/10.1002/2014GL061541, 2014.

Russell, P. B., Livingston, J. M., Pueschel, R. F., Bauman, J. J., Pollack, J. B., Brooks, S. L., and Dutton, E. G.: Global to microscale evolution of the Pinatubo volcanic aerosol derived from diverse measurements and analyses, J. Geophys. Res.-Atmos., 101, 18745-18763, 1996.

Sasano, Y., Browell, E. V., and Ismail, S.: Error caused by using a constant extinction/backscattering ratio in the lidar solution, Appl. Optics, 24, 3929-3932, 1985.

Sawamura, P., Vernier, J. P., Barnes, J. E., Berkoff, T. A., Welton, E. J., Alados-Arboledas, L., and Lange, D.: Stratospheric AOD after the 2011 eruption of Nabro volcano measured by lidars over the Northern Hemisphere, Environ. Res. Lett., 7, 034013, https://doi.org/10.1088/1748-9326/7/3/034013, 2012.

Schuster, G. L., Dubovik, O., and Holben, B. N.: Angstrom exponent and bimodal aerosol size distributions, J. Geophys. Res., 111, D07207, https://doi.org/10.1029/2005JD006328, 2006.

Siddaway, J. M. and Petelina, S. V.: Transport and evolution of the 2009 Australian Black Saturday bushfire smoke in the lower stratosphere observed by OSIRIS on Odin, J. Geophys. Res., 116, D06203, https://doi.org/10.1029/2010JD015162, 2010.

Solomon, S., Portmann, R. W., Garcia, R. R., Thomason, L. W., Poole, L. R., and McCormick, M. P.: The role of aerosol variations in anthropogenic ozone depletion at northern midlatitudes, J. Geophys. Res.-Atmos., 101, 6713-6727, 1996.

Solomon, S.: Stratospheric ozone depletion: A review of concepts and history, Rev. Geophys., 37, 275-316, https://doi.org/10.1029/1999RG900008, 1999.

Solomon, S., Daniel, J. S., Neely III, R. R., Vernier, J.-P., Dutton, E. G., and Thomason, L. W.: The persistently variable "Background"stratospheric aerosol layer and global climate change, Science 333, 866-870, https://doi.org/10.1126/science.1206027, 2011.

Solomon, S., Ivy, D. J., Kinnison, D., Mills, M. J., Neely III, R. R., and Schmidt A.: Emergence of healing in the Antarctic ozone layer, Science, 252, 269-274, https://doi.org/10.1126/science.aae0061, 2016.

SPARC: Assessment of stratospheric aerosol properties (ASAP): Technical report WCRP-124/WMO/TD-No. 1295/SPARC report no. 4, SPARC, Toronto, Ontario, CA 322, pp., 2006.

Stenchikov, G. L., Kirchner, I., Robock, A., Graf, H. F., Antuna, J. C., Grainger, R. G., Lambert, A., and Thomason, L.: Radiative forcing from the 1991 Mount Pinatubo volcanic eruption conditions, J. Geophys. Res., 103, 13837-13857, https://doi.org/10.1029/98JD00693, 1998.

Stenchikov, G., Robock, A., Ramaswamy, V., Schwarzkopf, M. D., Hamilton, K., and Ramachandran, S.: Arctic Oscillation response to the 1991 Mount Pinatubo eruption: Effects of volcanic aerosols and ozone depletion, J. Geophys. Res., 107, 4803, https://doi.org/10.1029/2002JD002090, 2002.
Taha, G., Rault, D. F., Loughman, R. P., Bourassa, A. E., and von Savigny, C.: SCIAMACHY stratospheric aerosol extinction profile retrieval using the OMPS/LP algorithm, Atmos. Meas. Tech., 4, 547-556, https://doi.org/10.5194/amt-4-547-2011, 2011.

Thomason, L. W., Pitts, M. C., and Winker, D. M.: CALIPSO observations of stratospheric aerosols: a preliminary assessment, Atmos. Chem. Phys., 7, 5283-5290, https://doi.org/10.5194/acp-75283-2007, 2007.

Thomason, L. W., Burton, S. P., Luo, B.-P., and Peter, T.: SAGE II measurements of stratospheric aerosol properties at non-volcanic levels, Atmos. Chem. Phys., 8, 983-995, https://doi.org/10.5194/acp-8-983-2008, 2008.

Trepte, C. R. and Hitchman, M. H.: Tropical stratospheric circulation deduced from satellite aerosol data, Nature, 355, 626-628, 1992.

Trepte, C. R., Veiga, R. E., and McCormick, M. P.: The poleward dispersal of Mount Pinatubo volcanic aerosol, J. Geophys. Res., 98, 18563-18573, 1993.

Trickl, T., Giehl, H., Jäger, H., and Vogelmann, H.: 35 yr of stratospheric aerosol measurements at Garmisch-Partenkirchen: from Fuego to Eyjafjallajökull, and beyond, Atmos. Chem. Phys., 13, 5205-5225, https://doi.org/10.5194/acp-13-5205-2013, 2013.

Vernier, J. P., Pommereau, J. P., Garnier, A., Pelon, J., Larsen, N., Nielsen, J., and McDermid, I. S., Tropical stratospheric aerosol layer from CALIPSO lidar observations, J. Geophys. Res.Atmos., 114, D00H10, https://doi.org/10.1029/2009JD011946, 2009.

Vernier, J.-P., Thomason, L. W., Pommereau, J.-P., Bourassa, A.,Pelon, J., Garnier, A., Hauchecorne, A., Blanot, L., Trepte,C., Degenstein, D., and Vargas, F.: Major influence of tropical volcanic eruptions on the stratospheric aerosol layer during the last decade, Geophys. Res. Lett., 38, L12807, https://doi.org/10.1029/2011GL047563, 2011.

Vignelles, D.: Caractérisation des performances du nouveau mini compteur de particule LOAC embarqué sous ballon météorologique: application à l'étude de la variabilité spatiale et temporelle des aérosols de la haute troposphère et de la stratosphère - PhD Thesis, Univ. Orléans, 2017.

Winker, D. M., Vaughan, M. A., Omar, A., Hu, Y., Powell, K. A., Liu, Z., Hunt, W. H., and Young, S. A.: Overview of the calipso mission and caliop data processing algorithms, J. Atmos. Ocean. Technol., 26, 2310-2323, 2009.

Weigel, R., Hermann, M., Curtius, J., Voigt, C., Walter, S., Böttger, T., Lepukhov, B., Belyaev, G., and Borrmann, S.: Experimental characterization of the COndensation PArticle counting System for high altitude aircraft-borne application, Atmos. Meas. Tech., 2, 243-258, https://doi.org/10.5194/amt-2-243-2009, 2009.

Wunderlich, F. and Mitchell, D. M.: Revisiting the observed surface climate response to large volcanic eruptions, Atmos. Chem. Phys., 17, 485-499, https://doi.org/10.5194/acp-17-485-2017, 2017.

Xu, W., Jónsson, S., Ruch, J., and Aoki, Y : The 2015 Wolf volcano (Galápagos) eruption studied using Sentinel-1 and ALOS-2 data, Geophys. Res. Lett., 43, 9573-9580, 2016.

Young, R., Houben, H., and Toon, O.: Radiatively forced dispersion of the Mt. Pinatubo volcanic cloud and induced temperature perturbation in the stratosphere during the first few months following the eruption, Geophys Res. Lett., 21, 369-372, 1994. 
Zuev, V. V., Burlakov, V. D., Nevzorov, A. V., Pravdin, V. L., Savelieva, E. S., and Gerasimov, V. V.: 30-year lidar observations of the stratospheric aerosol layer state over Tomsk (Western Siberia, Russia), Atmos. Chem. Phys., 17, 3067-3081, https://doi.org/10.5194/acp-17-3067-2017, 2017. 